\title{
Monetary, Subjective and Quantitative Approaches to Assess Urban Quality of Life and Pleasantness in Cities (Hedonic Price, Willingness- to-pay, Positional Value, Life Satisfaction, Isobenefit Lines)
}

\author{
Luca D'Acci
}

Social Indicators Research, DOI: 10.1007/s11205-012-0221-7 (in press)

The final publication is available at http://link.springer.com

\begin{abstract}
The magnitude increase of Urban Quality of Life studies is directly connected with the increase of the urban population in the world. Urban Quality of Life is a hierarchical multi-attribute concept whose attributes can be defined and evaluated by several kinds of methods such as Monetary (Hedonic Price, Willingness-to-pay, Cost-Benefit, Positional Value), Subjective (life satisfaction, subjective wellbeing, ranking/rating evaluation) and Quantitative (how many urban attractions there are in the city, and how they are distributed on its planimetry). As real examples of monetary approaches, 107 empirical literature results are briefly shown, quantifying the increase of property value in relation to urban factors such as green, open space, noise, public transport, pleasant view, etc. The result of a Willingness-to-Pay survey, and the definition of Positional Value are also shown; it is the part of property value coming from the characteristics of the area in which the property is. An analysis of Turin illustrated that the quality of the area (the Positional Value) can change the value of a property up to $143 \%$. This value is, in a certain way, a monetary mirror of the quality of life of the areas. As a concrete example of subjective approaches two rating method surveys on Turin are rapidly exposed, as well as a recent subjective wellbeing study comparing the life satisfaction in cities and in the countryside. As quantitative approaches are proposed the concepts of Isobenefit Lines and the Isobenefit Orography, both from the spatial urban amenities distribution and quantity.
\end{abstract}

Keywords: City Wellbeing, Urban Amenities, City Centres, Urban Economy, Citizens Happiness, Isobenefit Lines

\section{Introduction}

More and more people are choosing cities as the place where their lives will elapse. This part of the world's population is expected to be approximately 65\% by the year 2025 (Schell and Ulijaszek, 1999). Therefore, by building pleasant cities we can significantly improve the quality of life for billions of people.

Urbanization encourages fast social and economic growth, but at the same time, leads to many problems such as population density, traffic, lack in housing and resource, noise, air and water pollution, etc. (Li et at., 2009). We are progressively realizing to a greater extent the value of the quality of urban environment that will mitigate these problems (Shearer et al., 2006; Jenny and Ericson, 2006; Romano \& Ercolano, 2012), and several countries have already developed strategies to promote it (Costanza et al., 1997; Bolund and Hunhammar, 1999; Diamantini and Zanon, 2000). "The quality of the urban environment as a living space for the peoples of the world is an issue of fundamental concern for academic researchers, policy makers and citizens" (Pacione, 2003).

"Studying QoL in urban areas has attracted widespread research attention in recent years. Researchers from different fields, including geography, sociology, economy, psychology, political 
science, marketing and management, have participated in this area of inquiry (see: Das 2008; Grasso and Canova 2008; Dunning et al. 2008; Johansson 2002; Epley and Menon 2008; Rossouw and Naude 2008; Chen and Davey 2008; Marans and Stimson 2011)" (Rezvani, Mansourian and Sattari, 2012).

This paper will illustrate some possible methods to assess the Urban Life Quality (ULQ), and separates them among monetary, subjective and quantitative approaches.

\section{Urban quality of life as a Multi-attribute evaluation}

The ULQ is a hierarchical multi-attribute concept characterized by several underlying attributes that, in turn, are defined by more specific underlying attributes. These attributes are: environmental quality, air quality, green, jobs, social condition, urban quality, architecture quality, pedestrian areas, etc.

Estimating the urban quality of life is a complex quality assessment of many different features that must be considered simultaneously. The behavioural decision theory provides a number of methods for the analysis of multi-attribute objects/concepts.

Several methods are used to identify the relevant attributes of objects/concepts. For instance they can be elicited by reviewing literature, interviewing significant people (i.e. experts, residents), or by using common sense.

Among the techniques for interviewing, we can separate direct questioning and indirect questioning. In direct questioning the interviewee is asked to give a preference for an object and justify it. This technique is built on the presupposition that the respondent already knows well which attribute is determinant for his preference. It is also assumed that he is able to quantify the influence of each attribute on his preference.

Indirect questioning refers to any other survey technique in which the respondent is not directly asked which attributes determine his preference.

Two methodologies may be distinguished for structuring attributes: top-down method and bottomup method.

The top-down approach, also called analytic method, starts by creating a list of semi-specified relevant attributes characterising the object. In this case the object is the 'urban quality of life', therefore the 'object' is a 'concept' because is not a material entity like a car, house, or television.

A semi-specified, abstract attribute could be, for example, 'environmental quality'. It is split up into more specified attributes such as 'air pollution', 'traffic', 'green areas'...

The specification of the attributes continues until a level of attribute concreteness is reached and they can be adequately measured (e. g. concentration of toxic substance in the air in micro-Mole per cubic metre; sound pressure level in deci-Bells, square metre of public gardens...). These are the end-level attributes.

The bottom-up method is a synthesis of concrete, well-specified attributes that are grouped together to yield greater abstract, less well-specified attributes. This aggregation process of these so called higher-level attributes, into groups, is continued until only one attribute remains: the top-level attribute. Either in the top-down and bottom-up method, the more abstract the attributes are, the higher they are located in the hierarchy; the more specified they are, the further down they are.

The top-level attribute divides and grows into more and more detailed, concrete attributes until the end-level attributes form a 'value tree'.

\subsection{Attributes weights}

The weight of an attribute indicates its influence on the overall value of the object. The analysed object is the ULQ; the weight of the attributes that build it (green, pedestrian area, pollution, etc.), estimates how much each attribute influences the level of the quality of urban life. 
The concept of weight is defined with regards to specific theories of preference that can be categorised as preference aggregation - constructive modelling - and preference disaggregation reconstructive modelling. Therefore, the assessment of the attributes weights may be done in two ways.

In the constructive approach, the concept of the ULQ is built up from its underlying attributes. Their weights are directly measured by ranking or rating methods. In a ranking method the respondent is asked to set a list of attributes in order of importance $\left(1^{\text {st }}, 2^{\text {nd }}, 3^{\text {rd }}\right.$, etc. $)$. Several alternative variants have been proposed for this purpose, such as the pair-wise comparisons, which constitute the basis of the Analytical Hierarchy Process (AHP), the Multi-attribute Value Theory - for decisions under certainty - and the Multi-attribute Utility Theory - for decisions under risk. The term 'value' is used when the attributes are available to be quantified by an objective unit. The term 'utility' is used to express a subjective value received from the attributes. The pair-wise comparisons of the AHP judge the importance/influence of each attribute in relation to the others. For example, considering the object ULQ and three attributes such as air pollution, parks, pedestrian areas, the respondent is asked to say how much more or less important 'air pollution' is in comparison with 'parks' for the ULQ, then in comparison with 'pedestrian areas', then 'parks' in comparison with 'pedestrian areas'. Mathematical passages give the relative weights.

In a rating method he is asked to rate the list of attributes independently of one another.

In a reconstructive approach, the global judgement (value, preference, utility...) about the object, is broken down to yield the relative weight of the underlying attributes. The classical most used mathematical-statistical structure which allows this is the Multiple Regression. It is the basis of analysis like the Hedonic Pricing Method, the Conjoint Analysis, etc.

An example of attributes weights of the ULQ is shown in the following Fig. 1 where the weights of the attributes are deducted by a constructive method based on a rating evaluation surveying around 1300 people in a city of around nine hundred thousand inhabitants (Turin), (D'Acci 2008). They were asked to give a score from $1, \min$, to $5, \max$, to each attribute presented, in relation to the importance that they have regarding quality of life in cities. Fig. 1 shows the normalized results giving the relative importance in $\%$.
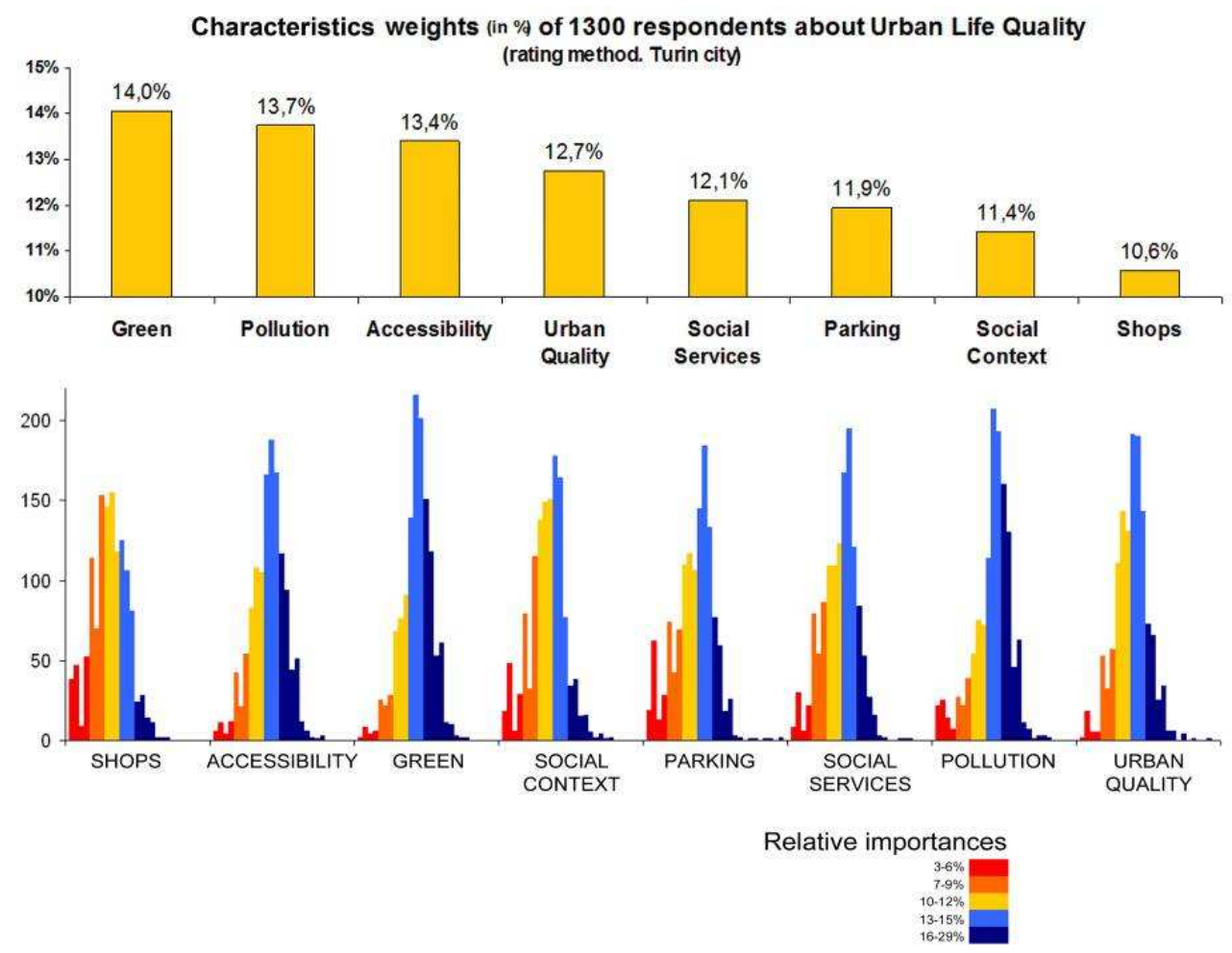

Fig.1 A rating method surveying 1300 people regarding some factors weights for ULQ 
Fig. 2 shows another example based on a rating evaluation surveying 515 people in Turin ${ }^{1}$.

How much these factors influence your urban unhappiness?

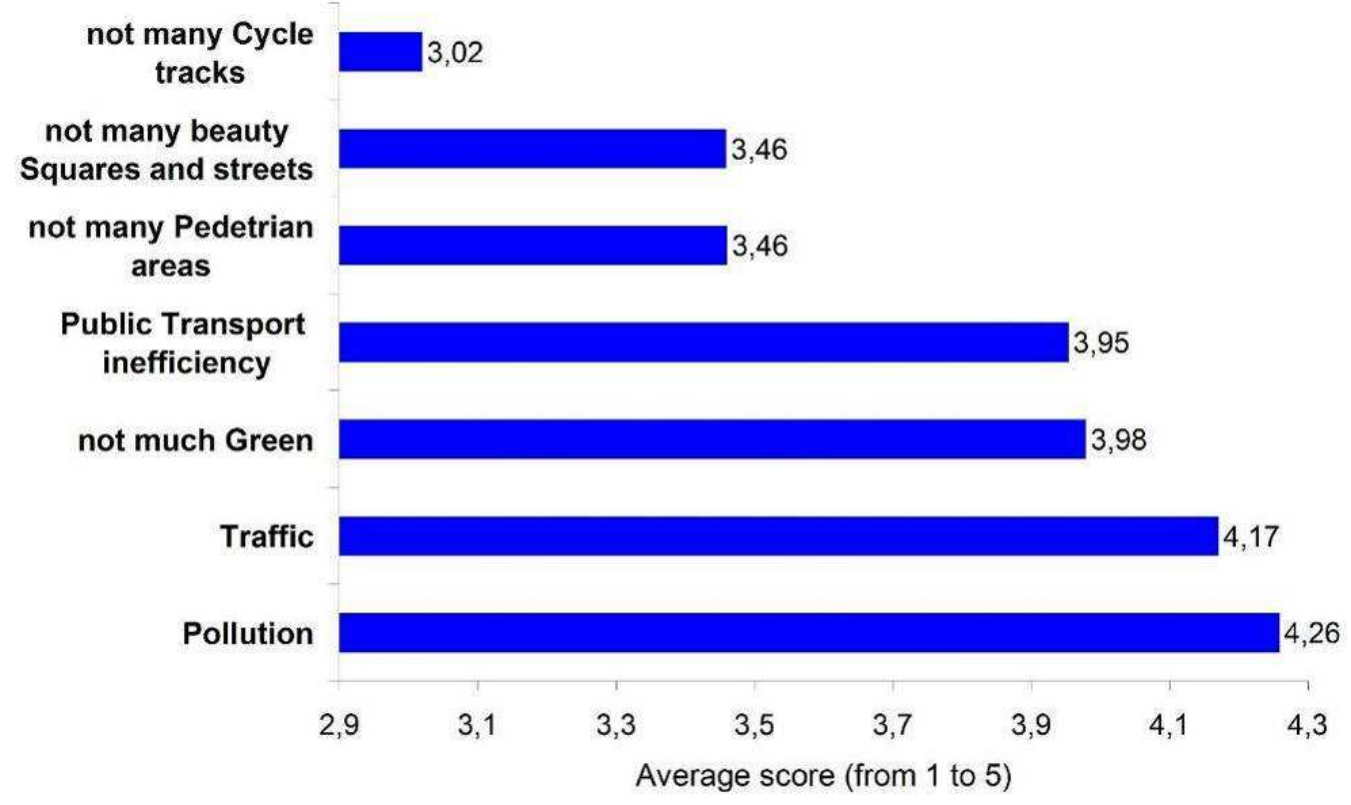

Fig. 2 Weight factors influencing urban non-liveability (rating method)

Fig. 3 shows the standard deviation of the replies in order to have an idea about the agreement of the citizens for each point.

\section{Disagreement of the replies}

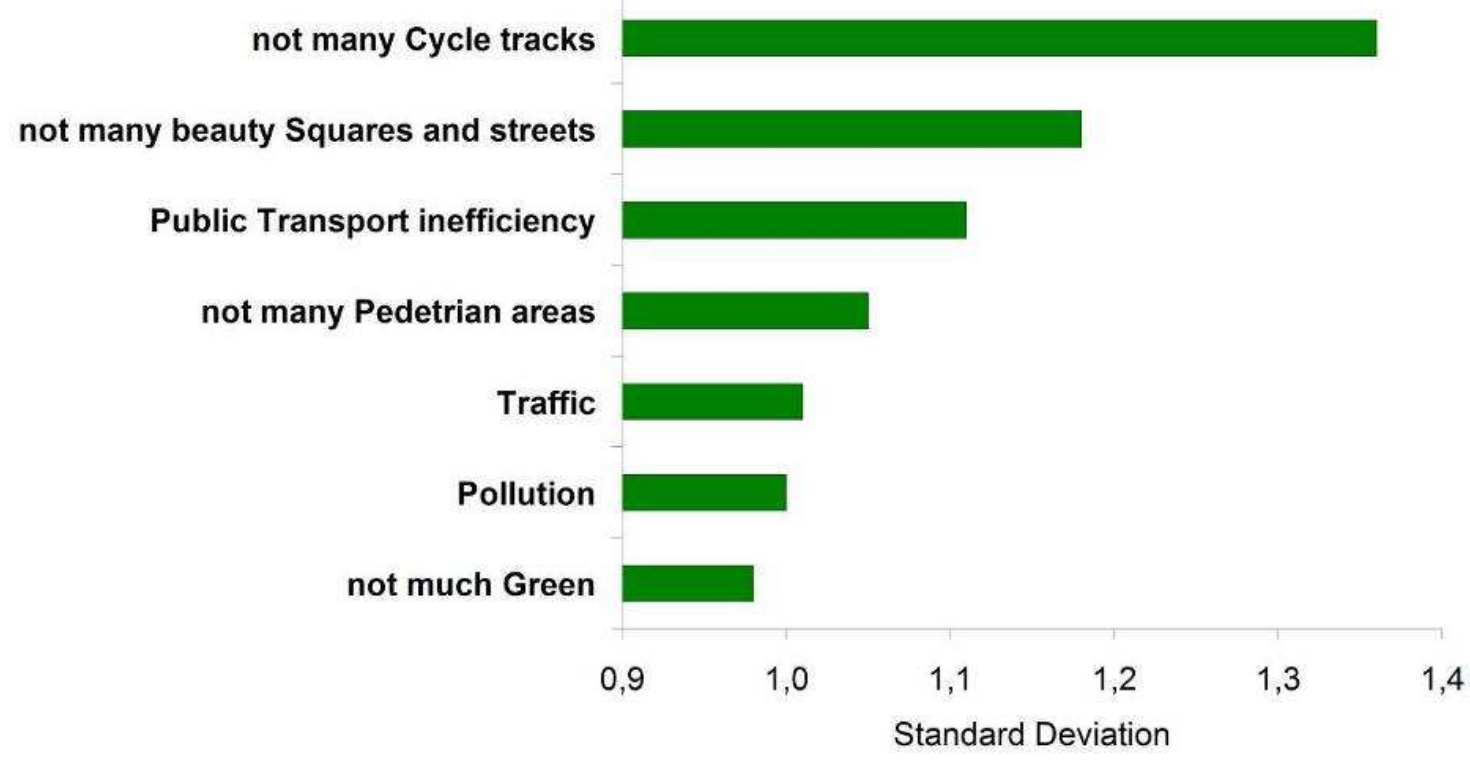

Fig. 3 Disagreement of the replies

\footnotetext{
${ }^{1}$ Part of a research conducted by the author in Turin in 2010 and currently under writing process.
} 


\section{Monetary Approaches}

The estimation of the urban life quality (ULQ) is a multi-attribute procedure that involves a monetary evaluation of various non-market costs and benefits, and the quantification of qualitative characteristics like aesthetics and 'feeling factors'.

\subsection{Hedonic Pricing Method}

The Hedonic Pricing Method (HPM) dates back at least to the 1920s. It was however only in the second part of 1900 s that it started to receive more attention. Some early applications focused on agricultural and, more recently, on the healthcare industry, housing market, artwork...

HPM has been used in a housing context to determine the impact of bads (e.g. pollution), or goods (e.g. public parks), on house prices.

The quintessence of HPM is that objects are conceived as possessing a value (or utility) composed by its constituting value of components. By this approach it is in part possible to consider the real estate value as a barometer for the state of the general quality of life that a citizen is expected to receive when buying a certain house in a certain city area.

The housing price is determined by intrinsic and extrinsic characteristics. The intrinsic characteristics are all the factors strictly connected to the house (flat, building) such as: number of rooms, windows, balconies, floor, building aesthetics, artistic finishes, technical facilities, etc.

The extrinsic characterises include all the factors describing the area in which the real estate unit is, such as: urban quality (quality of roads, buildings, squares), green (public parks and gardens), social context, public transport, proximity to the city centre (and/or some city cores), beauty views, historical value of the area, pollution (atmospheric, acoustic), etc.

Calling the housing price $P$, the intrinsic characteristics $I$, and the extrinsic $E$, we can express the price as function of $I$ and $E$ :

$$
P=f l, E
$$

In case of linear relations, the hedonic function can be described by the following simplified form:

$$
P=\alpha+\beta E+\gamma l+\varepsilon
$$

Having $n$ observations (number of housing prices known), $k$ intrinsic characteristics considered, and $m$ extrinsic characteristics considered, $P$ is an $(n \times 1)$ vector, $I$ is an $(n \times k)$ matrix, and $E$ is an $(n \times m)$ matrix; $\alpha, \beta$ and $\gamma$ are the associated coefficient vectors, and $\varepsilon$ is an $(n \times 1)$ vector of random error terms.

Having an accurate sample of housing units, their prices $(P)$, and their $I$ and $E$ measurements, the statistics offers several methods (e.g. multiple regression analysis), to deduct the influences $(\beta, \gamma)$ that each characteristics has on the formation of $P$.

The partial derivative of the function with respect to a characteristic represents the marginal price of that characteristic (also called hedonic or implicit price).

The hedonic price of each extrinsic characteristic, $P_{i}^{E}$, and the hedonic price of each intrinsic characteristic, $P_{i}^{\prime}$ can be expressed by the following equations:

$$
\begin{array}{ll}
P_{i}^{E}=\partial P / \partial E_{i} & (i=1,2,3, \ldots, m) \\
P_{i}^{I}=\partial P / \partial I_{i} & (i=1,2,3, \ldots, k)
\end{array}
$$


This is equivalent to saying that the coefficient $\beta$ (or $\gamma$ ) of a characteristic is the marginal price of that characteristic. In other words, it indicates how much the housing price increases (or decreases) just with regards to an increase of a unit of the value of a certain characteristic, keeping all the other characteristics fixed. For example, it shows how much $P$ increases when the characteristic 'green' increases of a unit but all the others remain the same.

If the relation between the characteristics (independent variables) and $P$ (dependent variable) is linear, we can use a linear regression (equation 2 ). The characteristics having a qualitative structure (i.e. the aesthetical), could be quantified in a numerical scale by comparative judgements among each area of the analysed city.

Then, for example, using a scale from 1 to 5 to quantify the characteristics, the marginal price of the characteristic 'green' states how much $P$ changes when the variable 'green' passes from 2 to 3 (or from 1 to 2,3 to 4 , etc.).

This information is given by its $\beta$ coefficient and, in the supposed linear condition, its geometrical meaning is showed in the Fig. 4: the coefficient is the angular coefficient of the straight line that relates $P$ and $E_{1}$.

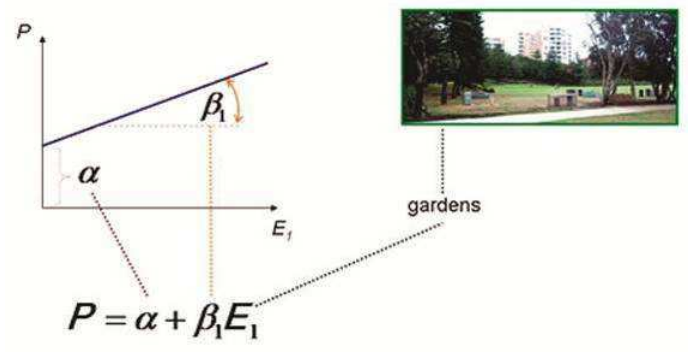

Fig. 4 Linear Regression geometrical meaning

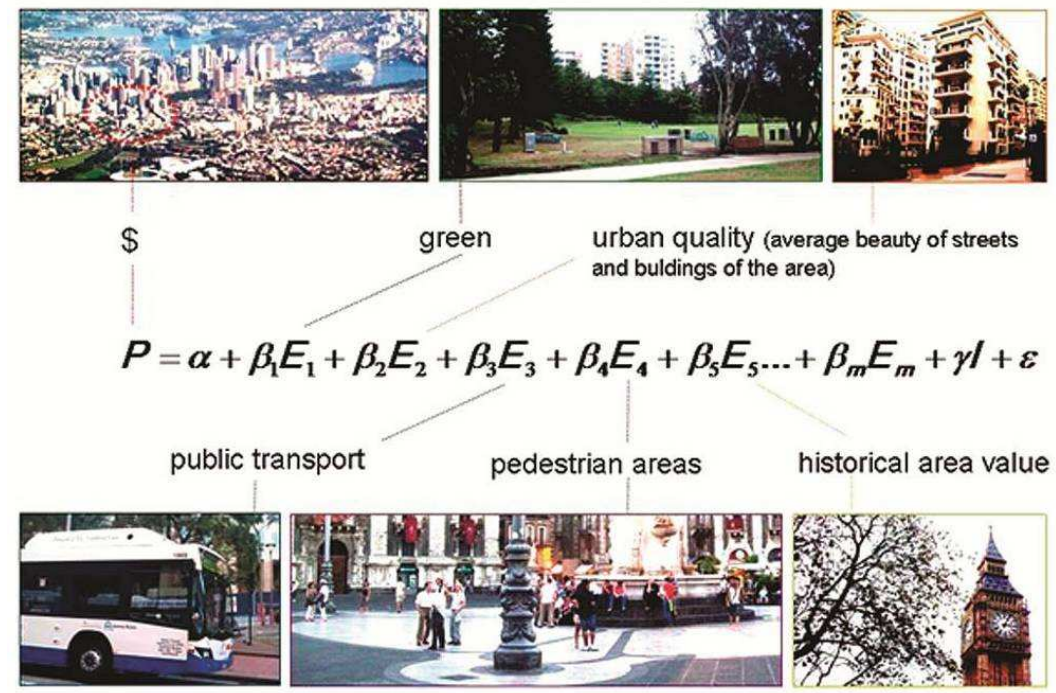

Fig. 5 Linear Regression example

The HPM applied for the real estate value, therefore suggests a way to quantify - and directly in monetary terms - the incidences of urban factors (Fig. 5) on the quality of life that citizens receive when buying their own house and living in a certain area of the city instead of another. Measuring the increase of property value means, in a certain way and under certain conditions, measuring the increase of the quality of life.

Table 1 (D'Acci 2012a) summarizes some empirical results about the relation between various extrinsic factors and real estate value (and then indirectly the quality of life), mostly deduced by HPM. 
Tab. 1

\section{Real Estate Value increases associated with urban quality, ceteris paribus}

\section{Proximity to green spaces}

$\mathbf{+ 5 . 9 \%}$ (Tajima 2003); $+\mathbf{1 1 7} \%$ after Centennial Olympic Park, in Atlanta, was built, adjacent condominium prices rose from $\$ 115$ to $\$ 250$ a square foot (City Parks Forum Briefing Papers, American Planning Association 2002); $\mathbf{+ 6 0 \%}$ (Fennema et al. 1996); $\mathbf{- 2 . 2 \%}$ for each $1 \%$ increase in distance from a park, $+\mathbf{5 \%}$ (a house that is $1 \mathrm{~km}$ away from a park is worth $5 \%$ less than an identical house adjacent to a park) (Troy \& Grove, 2008); marginal implicit prices of $\mathbf{\$ 3 4 2 / \$ 1 3 , 9 1 6}$ depending on park type and distance (Lutzenhiser \& Netusil 2001); $+\mathbf{\$ 0 . 2 4}$ per foot for a 1000 foot decrease in distance to parks (Wu, Adams \& Plantinga 2004); $+\$ \mathbf{\$ 2 4 6 / \$ 1 7 9 0}$ depending on park type when the distance between a home and park is halved (Anderson \& West 2006); $+\mathbf{1 0 \%}$ inner-city home located within $0.4 \mathrm{~km}$ of a park (Wachter \& Gillen 2006); $+\mathbf{0 . 0 1 6 \%}$ for a $1 \%$ decrease in distance from the parks, combining the mean real housing value and initial distance of 1 mile, the marginal implicit price would be $\$ 0.288$ : $+\$ 288$ by moving the house $1000 \mathrm{ft}$. closer to an urban recreation park (Poudyal , Hodges \& Merrett 2009); $+\mathbf{+ 1 8 0 0}$ every 100m further away from a green area (Morancho 2003); $\mathbf{\$ 2 0 9}$ million in the value of the property immediately adjacent to Central Park, New York, (\$13 million spent on its creation) from 1856 to 1873 (Frederick Law Olmsted, City Parks Forum Briefing Papers, American Planning Association, 2002); Central Park (NY): the annual excess of increase in tax from the $\$ 209$ million in property value was $\$ 4$ million more than the increase in annual debt payments for the land and improvement (City Parks Forum Briefing Papers, American Planning Association, 2002); $+\$ \mathbf{\$ 1 6 0}$ per household: $+\$ 6.5$ million (for 40984 properties within 1 mile from the urban parks) increasing by $20 \%$ the parks size (from 35.13 to 42.15 acres) (Poudyal , Hodges \& Merrett 2009); $+\$ 28$ per household for each additional acre of nearby natural area (Bolitzer \& Netusil 2000); +8/10\% (Crompton 2001); $\mathbf{- 5 . 9 \%}$ for an increase of $1 \mathrm{~km}$ distance (Tyrvainen \& Miettinen 2000); $\$ 302$ as a household's one time willingness to pay to preserve 5.5 acres of open space in the neighbourhood (Breffle, Morey \& Lodder 1998); garden vista, $+\mathbf{2 3 . 1 \%}$ (Jim \& Chen 2007); view of an urban park, $+\mathbf{1 8 \%}$ (Damigos \& Anyfantis 2011); view of green spaces, $+\mathbf{7 . 1 \%}$ (Jim \& Chen 2006), $\mathbf{+ 4 . 9 \%}$ (Tyrvainen \& Miettinen 2000); proximity to garden bordering on water, $\mathbf{+ 2 8 \%}$ (Luttik 2000, Tajima 2003).

\section{Pleasant view}

Pleasant view $\mathbf{+ 5 0} \%$, unpleasant view $\mathbf{- 2 5 \%}$, different view in the same district $\pm \mathbf{5} / \mathbf{4 5 \%} \quad$ (most probably about $\pm 15 \%$ ), view of the Acropolis (Athens) $\mathbf{+ 4 6 \%}$, presence of uncontrolled disposal sites $\mathbf{- 2 3} \%$, presence of industrial installations $\mathbf{- 2 1 \%}$, view to an abandoned quarry site $\mathbf{- 1 5 \%}$, view of the sea $\mathbf{+ 3 4 \%}$ (Damigos \& Anyfantis 2011); full sea view $\mathbf{+ 2 . 9 7 \%}$, confined sea view $\mathbf{+ 2 . 1 8 \%}$ (Jim \& Chen 2009); view of the sea, $+13 \%$ (Graves et al. 1988); full ocean view $+\mathbf{6 0} \%$, full ocean view adjacent to the coast $+\mathbf{6 8 \%} \%$, low-quality confined ocean view $+\mathbf{8 \%}$, poor views two miles from the coast $+\mathbf{4} \%$ (Benson et al. 1998); sea view $+\mathbf{1 8 . 5} \%$ (Kask \& Maani 1992), $\mathbf{+ 1 . 1 \%}$ (Hui et al. 2007), sea view $\mathbf{+ 9 . 3 \%}$ (Tse 2002), $\mathbf{+ 4 . 6 \%}$ (Hui et al. 2007), water view $+\mathbf{1 0 \%}$ panoramic water views $+\mathbf{6 5} \%$ (Bourassa et al. 2004); broad harbour view $\mathbf{+ 2 . 9 7 \%}$, confined harbour view $\mathbf{+ 2 . 1 8 \%}$ (Jim \& Chen 2009); scenic sight of water bodies $+\mathbf{8} / \mathbf{1 0} \%$, general attractive landscape $+\mathbf{5} / \mathbf{1 2} \%$ (Luttik 2000 ); river view $+\mathbf{7 . 8} / \mathbf{1 3 . 7 \%}$ ( Jim \& Chen 2007) $+\mathbf{2 8 \%}$ (McLeod 1984), lake view $\mathbf{+ 1 1 \%}$ (Smith 1994) $+\mathbf{4 4 \%}$ (Doss \& Taff 1996).

\section{Open spaces}

Degraded open spaces, partially reclaimed quarries, and low-flow -6\% (Damigos \& Anyfantis 2011); view of open space $\mathbf{+ 6 / 1 2 \%}$ (Luttik 2000); cleaning the air, acquiring open space, and creating parks and trails $\mathbf{+ 1 2 7 . 5 \%}$ (more than $\$ 11$ million) Chattanooga, in the early 1980s (City Parks Forum Briefing Papers, American Planning Association, 2002); proximity to cleaned-up vacant lot $+\mathbf{1 7 \%}$ (Wachter \& Gillen 2006); proximity to water bodies $\mathbf{+ 1 3 . 2 \%}$ ( Jim \& Chen 2006); proximity to open space $\mathbf{+ 0 . 1 3 7 \%}$ for each $10 \mathrm{~m}$ decrease in distance to open space (unweighted average effect of 52 hedonic pricing studies) (Brander \& Koetse 2011).

\section{Traffic, Noise, Pollution}

$\mathbf{- 5 \%}$ (Luttik 2000); $\mathbf{- 0 . 4 5 \%}$ per dB (Blanco \& Flindell 2011); $\mathbf{- 0 . 4 7 \%}$ per dB (Husted \& Anker 2004); -0.2\%/$\mathbf{0 . 3 8 \%}$ per dB (Schaerer, Baranzini, Ramirez \& Thalmann 2007); -0.2\% per dB (from a range of noise levels from 54 to $78 \mathrm{~dB}$ ) (Bateman, Day, Lake \& Lovett 2001); -1.07\% per dB (to noise levels greater than $68 \mathrm{~dB}$ ) (Lake, Lovett, Bateman \& Langford 1998); -0.36\% per dB (to noise levels greater than $55 \mathrm{~dB}$ ); airport, $\mathbf{- 9 . 2 \%}$ (Mcmillen 2004), - 2.4\% (Espey \& Lopez 2000); street view $\mathbf{- 3 . 7 \%}$, air pollution $\mathbf{+ 1 . 3 \%}$ than an identical one located in a neighbourhood whose annual average air pollution index was 1\% smaller (Jim \& Chen 2009); PCB pollution -3\%/$\mathbf{8 \%}$ for properties within two miles of the polluted site (Mendelsohn, Hellerstein, Huguenin, Unsworth, Brazer 1992); hazardous waste site, $-1.3 \% /-1.9 \%$ for each additional mile (Michaels \& Smith 1990), from $\mathbf{- 0 . 2 4 \%}$ to $\mathbf{- 2 5 \%}$

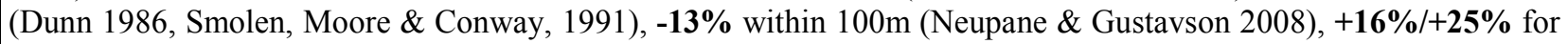
each additional mile from an active hazardous waste landfill (Smolen, Moore \& Conway 1991).

\section{Public Transport, Accessibility}

$\mathbf{+ 1 . 8 \%}$ for each additional transit line, $\mathbf{- 1 . 1 \%}$ for each additional minute in travelling (Ibeas, Cordera, dell'Olio, Coppola \& Dominguez 2012); +13/14\% (Bus Rapid Transit systems) (Rodríguez and Mojica 2009); $+\mathbf{1 0 \%}$ (Bus Rapid Transit systems) (Cervero and Kang 2011); $\mathbf{\$ 2 , 3 7 0}$ per hour of travel time saved (Dewees 1976); $+\mathbf{\$ 1 . 0 5}$ per feet distance to the station (Nelson 1992); $+7.3 \%$ for every dollar saved in daily commute costs (Allen et al. 1986); - 
$\mathbf{2 . 5 \%}$ for each $0.16 \mathrm{~km}$ distance from the metro station (Benjamin and Sirmans 1996); $\mathbf{+ \$ 2 , 2 3 7}$ near the rail lines (Bajic 1983); +7\% (Joint Center for Urban Mobility Research 1987); +\$5.714 for accessibility to train service (Voith 1991); $+\mathbf{1 0} / \mathbf{1 5 \%}$ within $0.4 \mathrm{~km}$ from railway station (Cervero 1996); $\mathbf{- 1 8 . 7 \%}$ within $0 / 0.4 \mathrm{~km}$ from railway station, $+\mathbf{2 . 4 \%}$ within $0.4 / 0.8 \mathrm{~km},+\mathbf{0 . 9} \%$ within $0.8 / 1.2 \mathrm{~km},+\mathbf{3 . 5} \%$ within $1.6 / 3.2 \mathrm{~km}$ (Bowes and Ihlanfeldt 2001$) ;+\mathbf{1 3}$ cents per square foot within $0-1 / 4$ mile from railway station, +7 cents within $1 / 4-1 / 2$ mile, +1 cent within $1 / 2-3 / 4$ mile (Weinberger 2001); within $0.4 \mathrm{~km}$ from railway station, $\mathbf{+ 3 6 . 7 5 \%}$ (retail) $\mathbf{+ 1 3 . 8 5 \%}$ (office), $\mathbf{+ 5 . 9 7 \%}$ (residential) $\mathbf{+ 7 . 6 8 \%}$ (industrial) (Weinstein \& Clower 1999); -\$1,593 for every $200 \mathrm{ft}$ out of the station (Dueker and Bianco 1999); $+\$ 31$ per square foot within $0.4 \mathrm{~km}$ of the station (Fejarang 1994); $\mathbf{+ 4 . 2 \%}$ within $0.4 \mathrm{~km}$ of the railway station (Debrezion, Pels \& Rietveld 2007); $\mathbf{+ 4 . 6 \%}$ within 500m of a Mass Transit Railway (the underground system) (Jim \& Chen 2009); $+\mathbf{1 6 . 4 \%}$ within $0.4 \mathrm{~km}$ of the railway station (Debrezion, Pels \& Rietveld 2007); city centre location, $+9.1 \% /+10.5 \%$ (Schaerer, Baranzini, Ramirez \& Thalmann 2007); accessibility to central locations (Central Business District, $\mathrm{CBD}$ ), $\mathbf{- \mathbf { 0 . 8 } \%}$ per minute increase in the time required for a resident to travel from his apartment to CBD (Hui, Chau, Pun \& Law 2007).

\section{Pedestrianised areas}

Economic activity: footfall for retail services, $\mathbf{+ 2 0 \% / + 4 0 \%}$ (Hass-Klau 1993), $+\mathbf{3 2 \%}$ (Gehl \& Gemzøe 1999, Pearson 2000), impacts on retail turnover, $+\mathbf{1 7 \%}$, a range of $+10 \%$ to $+25 \%$ is suggested (Newby 1992 , Hass-Klau 1993, Saretzki \& Wohler 1995, the European Federation for Transport and Environment 2002), retail rents, $+22 \%$, a reasonable range is +10 to $+30 \%$ (Hass-Klau 1993, Colliers Erdman Lewis 1995, Hass-Klau \& Crampton 2002).

\section{Schools}

Proximity to schools, $\mathbf{+ 0 . 1 \%}$ for each additional reputable secondary school located in that district (Hui, Chau, Pun \& Law 2007).

\section{Urban revitalization}

New housing, $+\$ \mathbf{6 7 0}$ for each new housing construction within 2-3 blocks (Simon, Quercia \& Maric 1998), +6.1 \$cents for each $1 \$$ invested of new residential construction within 46 meters $(+\$ 5000$ for a new house constructed nearby with an average investment of \$82000) (Ding, Simons \& Baku 2000); waterfront regeneration, office rents from $+3 \%$ to $+53 \%$ (Frederick \& Goo 1996); improvements of green areas, housing, shops, pollution, streets/squares quality, from $+8 \%$ to $+63 \%$ (D'Acci $2007,2008,2009 b$ ).

As table 1 shows, the impact estimated for the same factor can vary widely from one research to another. This is probably due to several causes such as different variables, different methods (D’Acci, 2012 b), different cities, different times, etc.

\subsection{Cost-Benefit Analysis}

A cost-benefit analysis estimates the total equivalent monetary value of the benefits and costs to the community to judge the feasibility of a project (or decision, government policy, etc.), from a social point of view, or to compare several projects. It dates back to the middle of the ' 800 with the French engineer Jules Dupuit. Therefore, some of the formal concepts that are at its basis were formulated from the British economist Alfred Marshall.

It compares the total expected cost against the total expected benefits, to evaluate if the benefits prevail over the costs, and by how much. All flows of costs and benefits over time have to be expressed in monetary terms, and temporally adjusted on a common basis at the same present time.

The cost-benefit approach can be used to estimate some aspects related to the ULQ such as the social cost of commutation, pollution, etc.

For example in Ningbo city the commutation time in 2001 was at average 120 minutes, a $50 \%$ increase from 1990; similar results concern the cities of Guangzhou and Yangzhou with their average commutation time in 2001 of 90 and 150 minutes (Wen \& Chen 2008). The value due to time lost could be calculated as the total annual amount of time vanished in commutating multiplied by the average income per hour.

Part of the cost of urban pollution can be evaluated by estimating the costs of health problems caused by pollution, investigating the relationship between pollution and the death rate or morbidity of a given disease, and multiplying the exposed population with the estimated morbidity to derive the cases of illness caused by certain pollution. To estimate the monetary losses of those sickness 
cases it is possible to use the Human-capital Approach. It transforms the pathological losses, such as sick leave and days off due to the illness, into monetary cost. In addition the medical treatment expenditures are considered too.

\subsection{Willingness-to-pay}

By this method the interviewee is asked what he would be willing to pay for a product/service/feeling, or to maintain the existence of it, or what compensation he would accept for its loss. In the last two cases we talk about Contingent Valuation.

For example, it could be asked the willingness-to-pay for a reduction of traffic and air pollution, or an increase of bike lanes, parks, pedestrian squares, or for not allowing a nice present pedestrian square becoming non-pedestrian, or a nice public garden becoming a car street, etc.

There are two main approaches to estimate the willingness-to-pay: the stated preferences, and the revealed preferences.

In the methods based on the stated preferences, the surveyed is directly asked his willingness-to-pay for, or is asked to chose among a number of hypothetical scenarios (i.e. conjoint analysis), that differ for the price $(P)$, and the characteristics we want to estimate the value (i.e. parks in front the house, noisy traffic in front the house, public transport, distance from the city centre, etc.).

The revealed preferences approaches include all the methods based on the real market choice of people: what they really have chosen and bought (i.e. HPM).

Next Fig. 7 shows an example of a Willingness-to-Pay survey of 515 people in Turin in $2010^{2}$.

The sample appreciably covers different age and income ranges, but is not statistically significant because of its number and because most of the interviewed are graduated and even pos-graduated ${ }^{3}$.

By asking "How much could you pay monthly for a high improvement of the quality of the area where you live?", the mean Willingness-to-pay resulted was $45,4 € /$ month.

In order to find out the relations among Willingness-to-pay/income/quality of the area where one already lives, it was asked to give a score $(1, \min , 5, \max )$ to the quality of the area where the interviewed lives (bottom of Fig. 6).

Considering that the survey was carried out in the city of Turin, and knowing that its number of families is 441.915 (www.comuni-italiani.it/001/272/statistiche/), if we imagine (keeping in mind all the statistical limits and the non significance of the sample and of the structure of this survey), that each family, in average, could be available to pay $45,4 € /$ month to improve their average underground welfare given by the quality of the area where their house is, we would have around 241 million $€ /$ year, namely about 2.4 billion $€$ in 10 years in a city of about nine hundred thousand residents as Turin.

\footnotetext{
2 The survey was built by the author when he researched at Politecnico di Torino.

${ }^{3}$ Age: ' $18-30$ ' 162, ‘31-50' 281, '51-70’ 66, ‘ $>70$ ’ 3. Without degree 53, graduated 214, pos-graduated 245.
} 
How much could you pay for a high improvement of the quality of your area (green, pedestrian areas, efficient public transport, beauty of buildings, streets and squares...)?
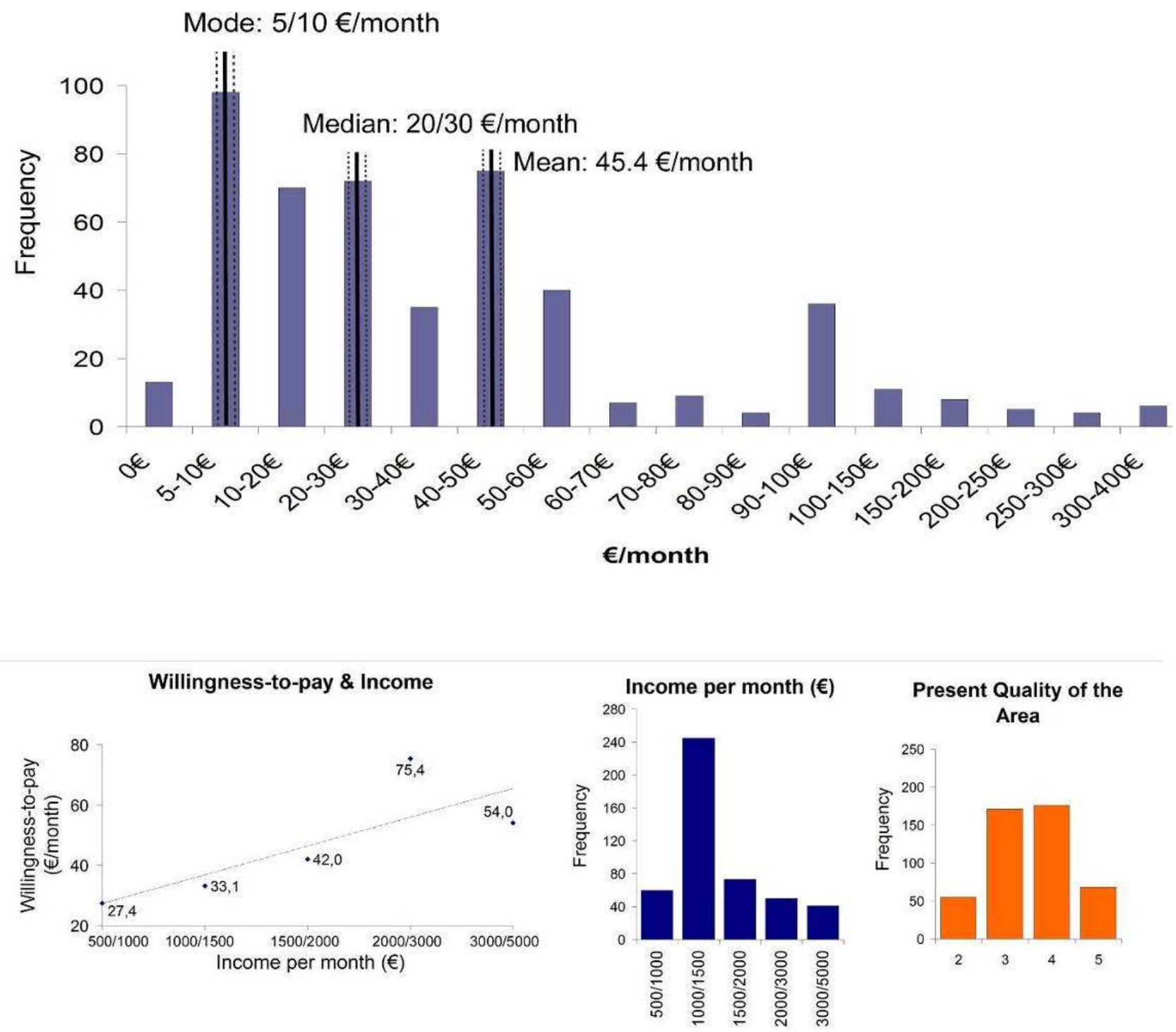
Present Quality of the
Area
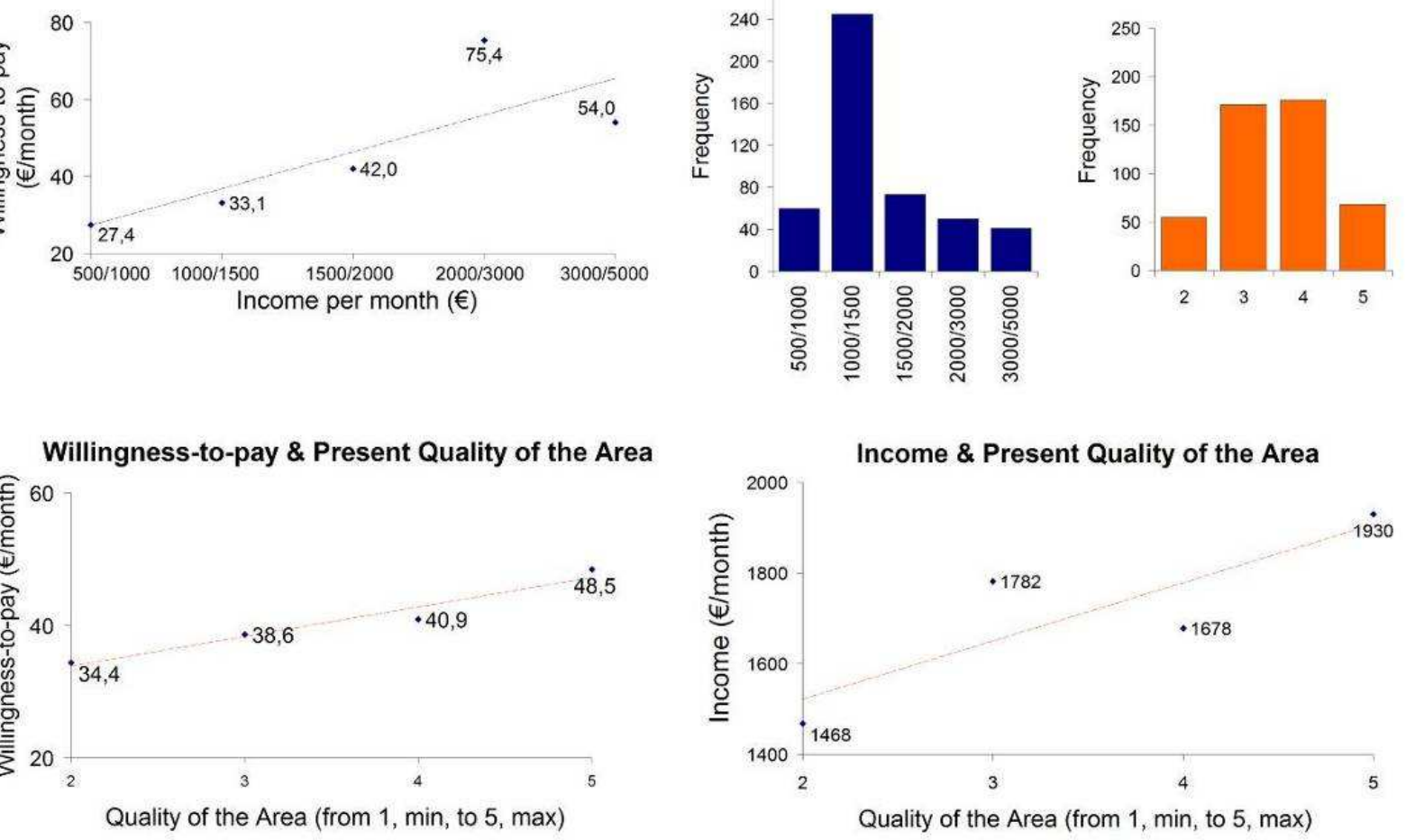

Fig. 6 A Willingness-to-Pay analysis for Turin 


\subsection{The Positional Value ${ }^{4}$}

The housing price is determined by intrinsic and extrinsic characteristics. The intrinsics are all the factors strictly connected to the house (flat, building) such as: number of rooms, windows, balconies, floor, building aesthetics, artistic finishes, technical facilities, etc.

The extrinsic characteristics include all the factors describing the area in which the real estate unit is, such as: urban quality (quality of roads, buildings, squares), green (public parks and gardens), social context, public transport, proximity to the city centre (and/or some city cores), beauty views, historical value of the area, pollution (atmospheric, acoustic), etc. We call Positional Value (PV) the part of the real estate value given from the extrinsic characteristics.

An example of a calculation of PV is shown by a research on Turin using a sample of 400 real estate observations covering the area of Turin ${ }^{5}$. In order to estimate the PV, a real estate sample was selected looking at the closest possible match regarding the intrinsic characteristics (features of the building such as aesthetics, level of finishing, etc., and the specific apartment factors such as layout, floor, rooms, brightness and so on). Outside a given range of dissimilarities, apartments were not to be included in the sample, and small dissimilarities still existing in the sample were equalised through a Sales Comparison Approach.

The result is that the characteristic of the area (accessibility, green, pollution, social context, elegance of the urban context, etc.) can rise the property value up to $143 \%$ its value (Fig. 7, 8). This is also a way to quantify the quality of life of the area because usually, the willing to pay of ordinary citizen for his residential house is directly connected to the quality of life he is supposing to receive by living in that area (extrinsic characteristics - Positional Value) and in that building/flat (Intrinsic characteristics).

\footnotetext{
${ }^{4}$ D'Acci, 2012a.

${ }^{5}$ Data from D'Acci (2007).
} 


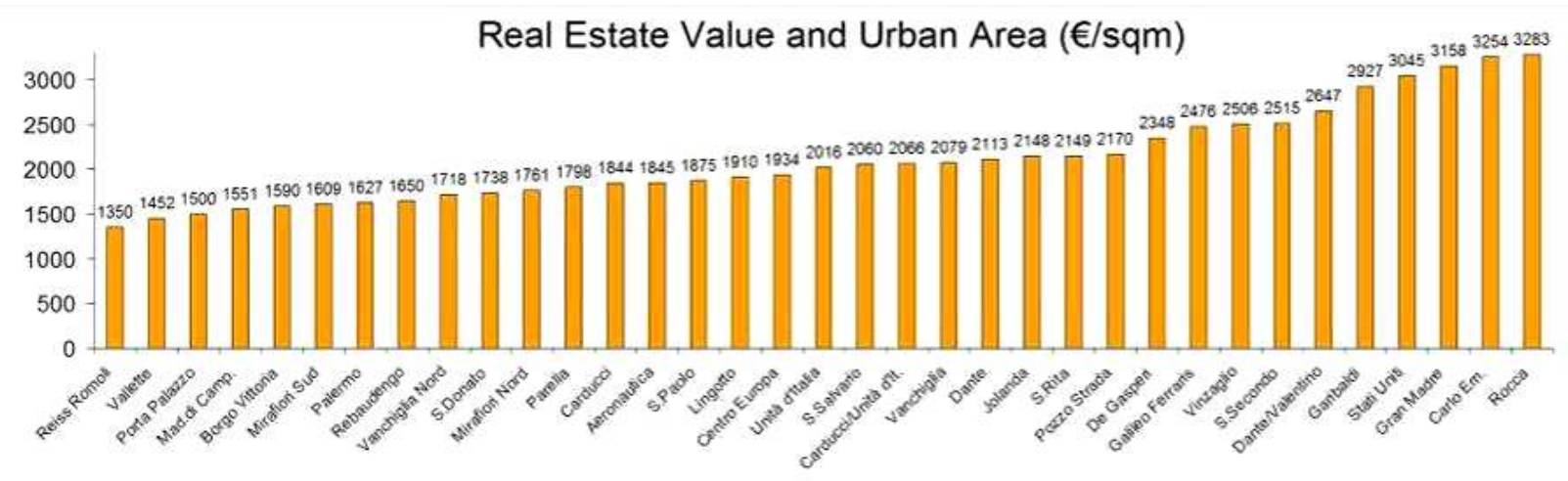

Ceteris Paribus for the Intrinsics
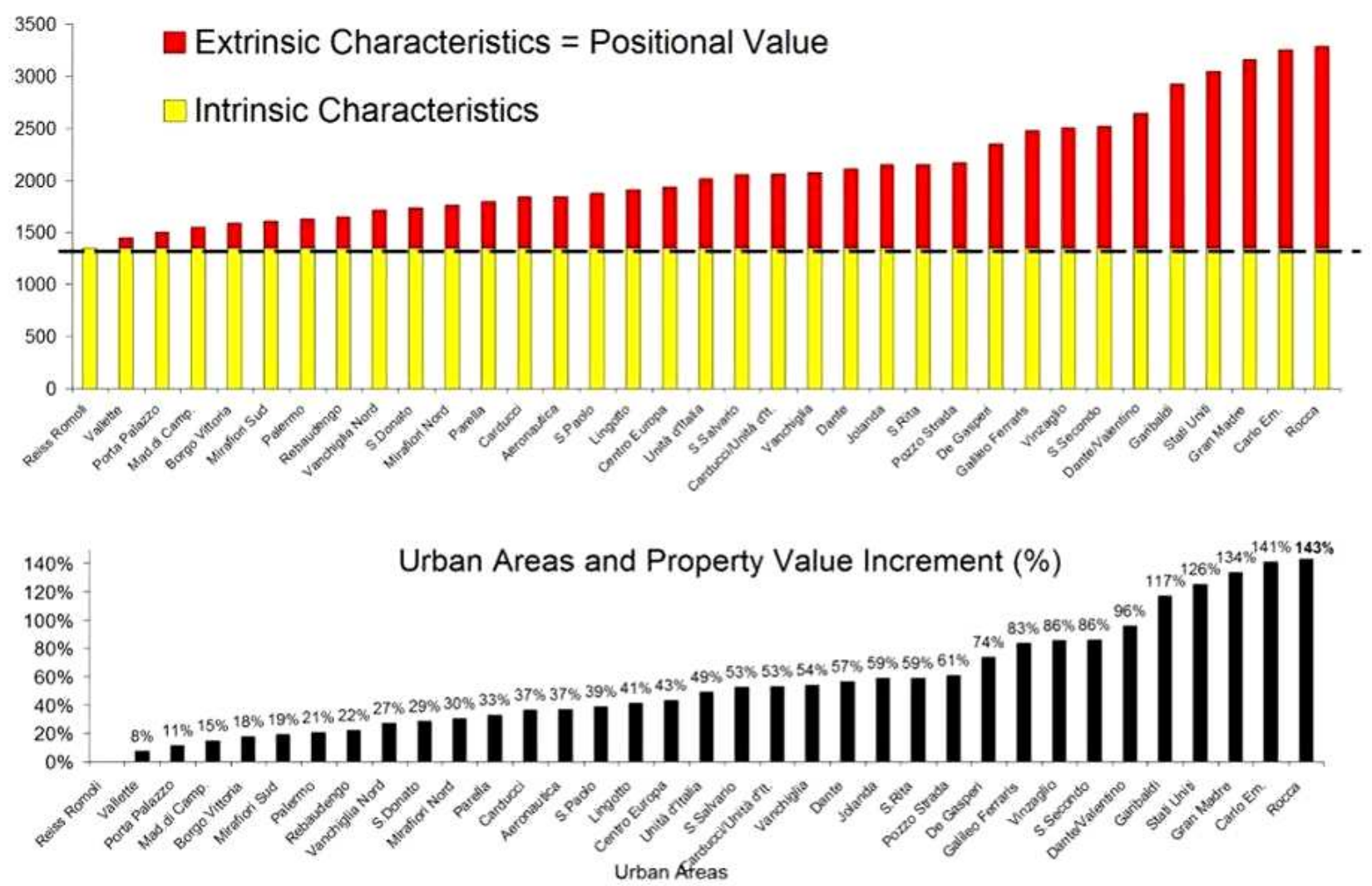

Fig. 7 Increase of the Positional Value in Turin areas. 


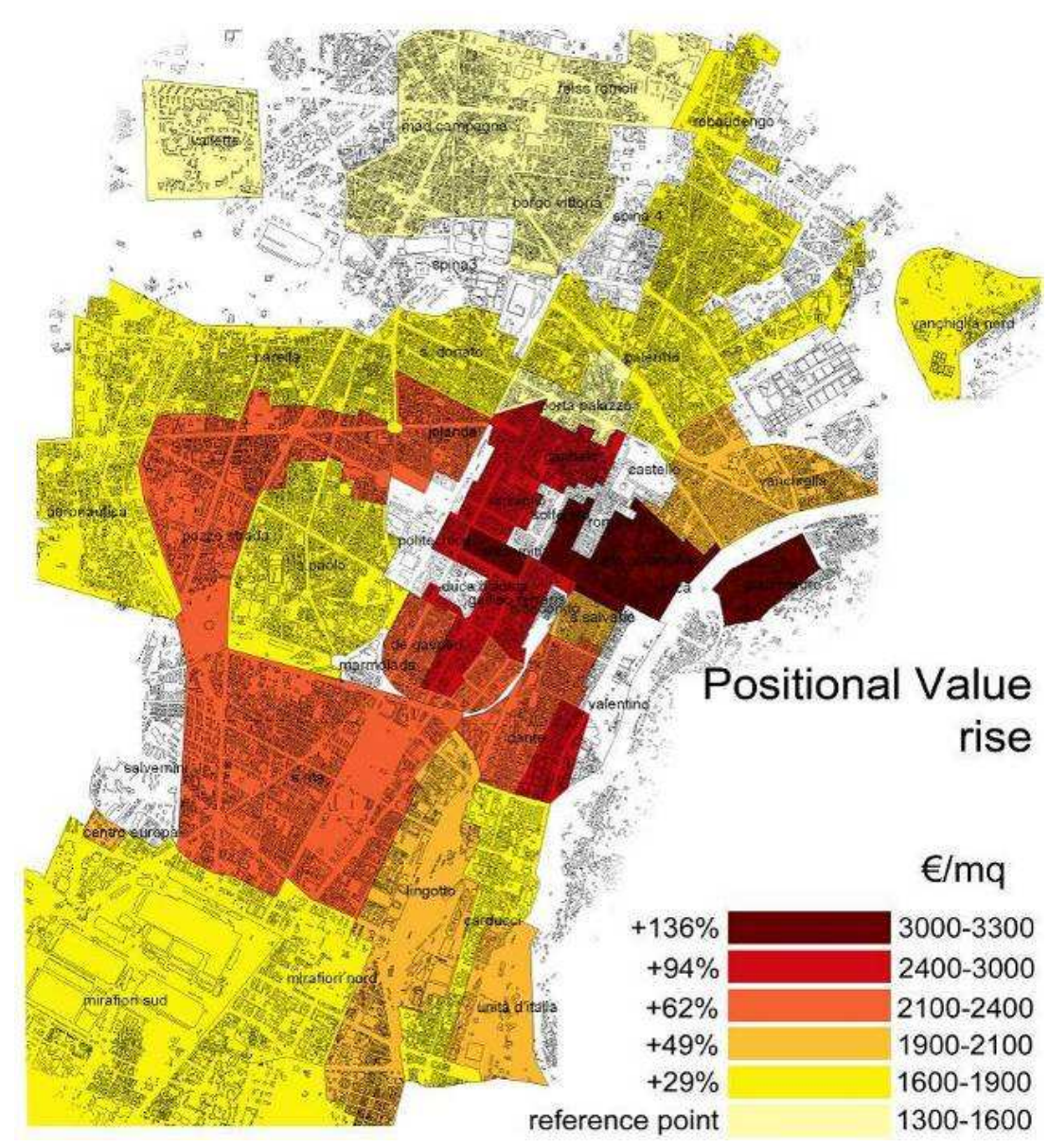

Fig. 8 Planimetrycal distribution of the Positional Value in Turin

\section{Subjective Well-Being Approaches}

In observance with the economics literature, subjective well-being covers measures of both happiness and life satisfaction. As an example of this kind of analysis applied to estimate happiness in the city, we refer to a recent investigation (Easterlin, Angelescu, and Zweig 2011), involving a survey in which respondents are asked to quantify their feelings about their life on a scale from 0 to 10 (life satisfaction, LS). A series of regressions deducted the weights of factors such as living in an urban or rural environment, income, education and occupational structure (independent variables) on the life satisfaction (dependent variable). The excess of urban over rural happiness tend to vanish and even reverse, as occupations, incomes and education in urban and rural areas converge.

Fig. 9 shows the urban-life-satisfaction ULS (ordinate) and rural-life-satisfaction RLS (abscissa) for 80 countries surveyed.

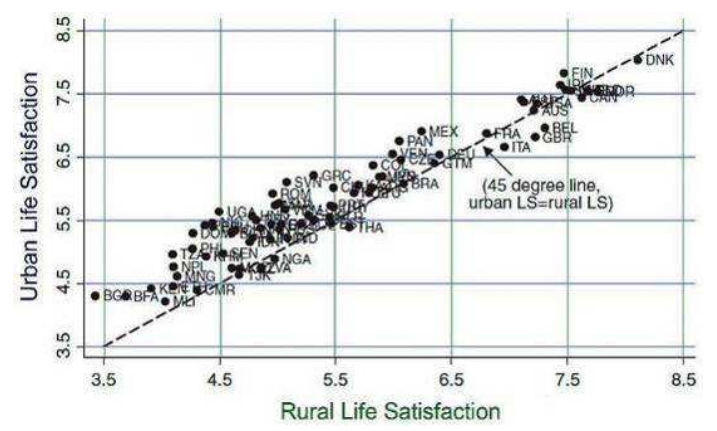

Fig. 9 From Easterlin, Angelescu, and Zweig 2011, fig. 3 
If ULS and RLS are the same, the coordinates fall into a point on the bisector. When ULS is higher than RLS, the point is above the bisector, and vice versa. Fig. 9 shows that the points are mostly above the bisector, that means that in most of the countries urban inhabitants expressed to feel more satisfied than rural inhabitants.

Fig. 10 shows the ULS minus RLS when the factors income, education and occupational structure are inserted into the analysis (we can call it $\{\text { ULS-RLS }\}^{*}$, and represents the ordinate axis), and when they are not inserted ( $\{$ ULS-RLS $\}$, abscissa).

The bisector in Fig. 11 then indicates the points with $\{\text { ULS-RLS }\}^{*}=\{$ ULS-RLS $\}$. If even with the control of these factors, ULS minus RLS was the same, the points would be on the bisector, and the meaning would possibly be: people feel happier living in cities not because of a higher income, education and better occupational structure, but because they really prefer living in cities (for some other reasons). However Fig. 10 illustrates that most of the points are below the bisector. This suggests that interviewees feel happier in cities mostly because of reasons such as income, education and occupation, but, if they could have the same level of them both by living in rural and urban areas, ULS-RLS reduces or even inverts the sign.

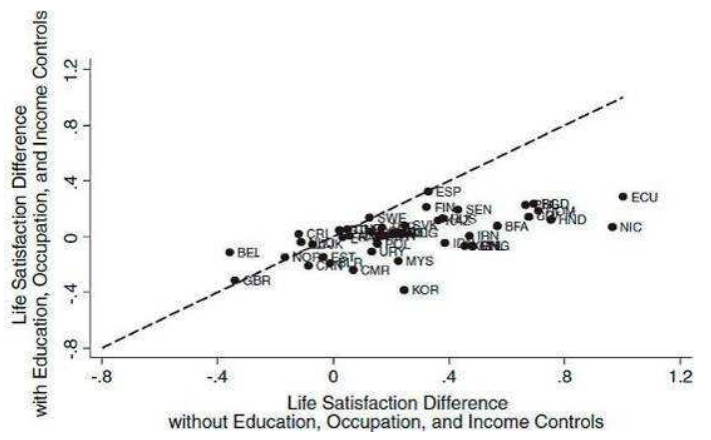

Fig. 10 From Easterlin, Angelescu, and Zweig 2011, fig. 7.

We cannot put the calm picturesque of countryside life into the city (as well as we cannot put the fizzy culture, modernity and history of cities into the countryside) but, by planning good cities we could increase their attractiveness; not just because in the city one can have a higher income or education, but because one lives in a beautiful city. Graphically it means to shift the line of the linear interpolation of the points in Fig. 10 toward the bisector (Fig. 11).

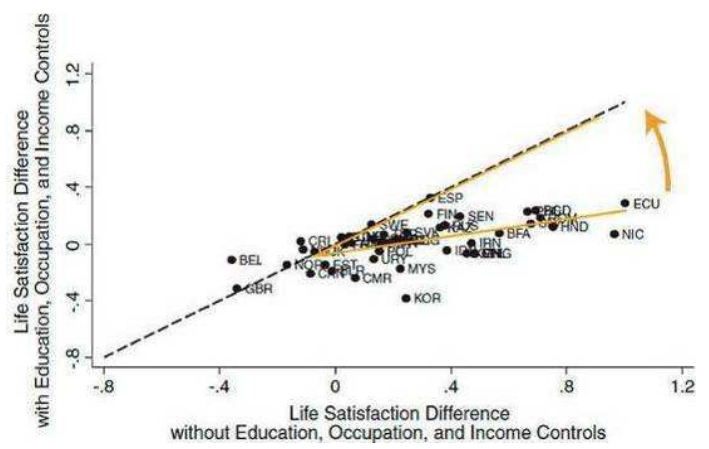

Fig. 11 Modification from Easterlin, Angelescu, and Zweig 2011, fig. 7

"Several authors suggest that quality of life is embedded in the cultural and social context of both the subject and the evaluator (Campbell et al. 1976; Kahneman et al. 1999), and objective characteristics of a society, like poverty, crime rates, and pollution, contribute significantly to people's judgements of their lives (Kahneman et al. 1999)" (Lopes and Camanho, 2012). Other 
authors recommend "to pay more attention to subjective indicators of quality of life. After all, what matters is what we perceive, not what is out there" (Okulicz-Kozaryn, 2011).

The Hedonic Underground Theory (D'Acci 2012c), formulizes this importance, and the subjectivity, that the background pleasantness of the cities where we live has on our underground subjective wellbeing. It measures the underground mood by passing through the idea of Hedonic Inertia, defined as the substratum residual feeling given by the experiences lived in each different moment of the day. It also refers to our general situation (love, career, money, national politics, etc.), and from the background scenario of our daily activities (urban beauty, noisiness, comfort, etcetera).

\section{Quantitative Approaches: Assess the Distribution of Pleasantness in Cities}

Quality of life in cities also depends on how the factors inducing a pleasant life are spatially distributed throughout the city.

I propose a separation between Pleasantness given from city Centralities $(P C)$ and Pleasantness given from the Background 'daily urban quality' $(P B)$.

We can define a city centrality as a part of the city containing a high level of concentration of public cultural assets such as libraries, museums, art galleries, public buildings and open spaces, higherorder commercial and retail functions, notable and memorable historic buildings and spaces, etc. (Bianchini 1990, Evans 1997). Apart from a 'concentration of several attractions', we can also refer as city centralities, single amenities important at a city level (i.e. Ibirapuera Park in São Paulo, Parc de la Villette in Paris, Valentino Park in Turin, Central Park in New York, etc.)

Even if nowadays we assist a general aim and tendency to generate multicentre cities, in several cases the first and most important centrality is still the traditional, historical city centre. Apart from that citizens living directly in, or very close to, a city centrality, $P C$ is connected then to the will of going to a city centrality.

$P B$ derives from the pleasantness given from the city's beauties present in our own daily lives: where we are living and working, or passing through such as a local little garden or square, the average quality of the streets, and so forth (D'Acci 2009b). $P C$ is at "city level"; $P B$ is at "local level" and "fuzzy", we could also define it as Fuzzy Urban Quality.

In order to asses the distribution of the Pleasantness given from city Centralities $(P C)$, it is functional to propose a separation between Punctual Benefit $(A)$ of an attraction, and its Distributed Benefit (B), (D'Acci 2009a, b). The first concerns to the benefit obtained when the citizen is using the amenity (park, square, etc); the second the benefit of every urban point, given from the attraction. The Distributed Benefit is then associated to the citizens' facility of using directly the city's attraction and depends on the benefit $(A)$ offered by the attraction $(i)$, the distance $(d)$ between the citizen location $(k)$ and the attraction $(i)$, and the cost/comfort/speedy - we can call $E$ these three factors - of reaching the attraction:

$$
B_{i, k}=A_{i} \cdot E / d_{i-k}+E
$$

Where $B_{i, k}$ is the Benefit in a $k$ urban point, generated by an $i$ attraction having an $A$ level of Punctual Benefit, and $d_{i-k}$ is their distance. The Punctual Benefit, $A$, concerns the benefit obtained when the citizen is using the public-good (i.e. the 'pleasantness'-benefit felt by the citizen when he is in a park, pedestrian street...). It could also be contemplated and evaluated by thinking and comparing the public places in the city where the majority of citizens (principle of ordinariness) decide to go for a walk and to spend their free time; or can be deducted by one of the methodologies to quantify the influences of urban characteristics (parks, pedestrian areas...) on the quality of life 
(i.e. Hedonic Pricing Method, Willingness-to-Pay...), or by asking every citizen to express their own judgement ${ }^{6}$.

We should include the number of people ( $D=$ density of population) living in the different urban areas and add it into the equation $\left(B_{i, k} \cdot D_{k}\right)$. However, for simplicity, this paper will consider just one density population covering the city. Then, being constant, it will be possible to not consider it at all. Fig. 12 shows a graphical simulation example of Punctual and Distributed Benefit.
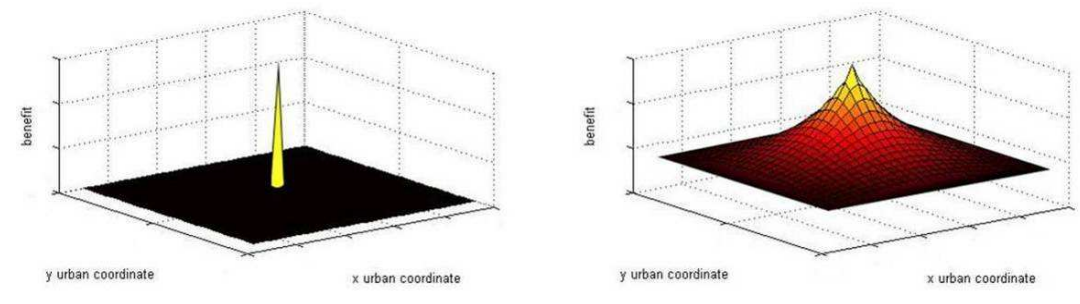

Fig. 12 Punctual (left) and Distributed (right) Benefit

I define curves of spatial social isobenefit (or Isobenefit Lines ${ }^{7}$ ), the lines that join the urban points $(k)$ with the same level of $B$. The next Fig. 13 shows the isobenefit lines of the attraction of the previous example.
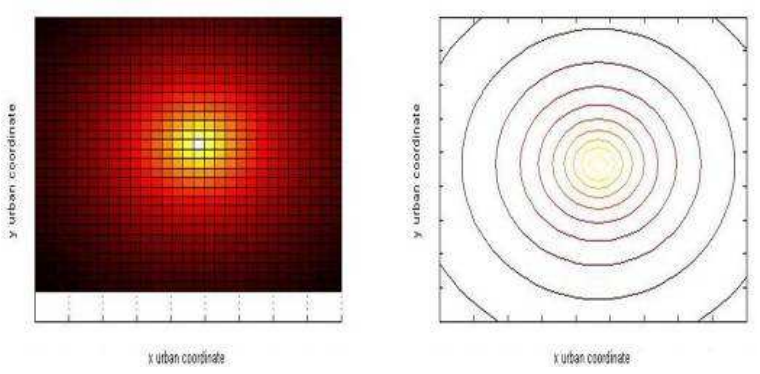

Fig. 13 Isobenefit lines

Considering now all the attractions present in a city, $B_{k}$ is the benefit of the $k$ urban point given by all the attractions in the city, and it depends on the distance, level, number and reciprocal positions of attractions:

$$
B_{k}=\sum_{i=1}^{n} A_{i} \cdot E / \phi_{i-k}+E
$$

\footnotetext{
${ }^{6}$ Personal Isobenefit Lines (D'Acci 2012d, e, f).

7 They were introduced by D'Acci $(2012 \mathrm{~d}$, e, f) and underlined by the MIT Technology Review as: "Isobenefit Lines rewrite rules for understanding city life. A new way of mapping cities according to the benefit they give residents has the potential to change the way planners think about city design. [...] In recent years, city planners have begun to place more emphasis on developing additional centers within cities. So it's increasingly common for a city to have several centers performing different functions. D'Acci's new model is designed to cope with this increased complexity. [...] D'Acci's approach is clearly a step forward. He points out that there is a strong correlation between isobenefit lines and property prices. That's a good indication that the model captures some important elements of human behavior" (MIT Technology Review 2012). MIT Technology Review was founded at MIT in 1899.
} 
We can then have different social isobenefit scenarios depending on the planimetric distribution of the attractions throughout the city. We call them isobenefit orography.

We call $\mathrm{M}$ the matrix of $m$ elements (the number of cells we have divided the city into, Fig. 14), where the generic $k$ element has a value $B_{k}$, and $B^{\prime}$ is the medium value of $\mathrm{M}$ :

$$
M^{\prime}=B^{\prime}=\frac{1}{m} \sum_{k=1}^{m} B_{k}
$$

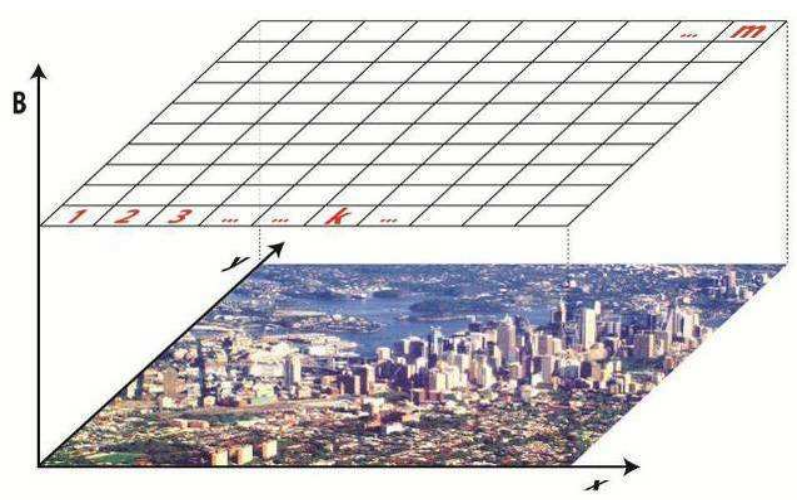

Fig. 14 The Urban Matrix (M)

To quantify the uniformity of the spatial distribution of the social benefit we can use as easy indicator the coefficient of variation $(\mathrm{CV})$ of the urban Matrix M: the standard deviation of the $B_{k}$ of every urban point $(\sigma M)$, divided by its medium value $\left(M^{\prime}\right)$ :

$$
\underset{V}{C}=\sigma M / M^{\prime}=\sqrt{\frac{\sum_{k=1}^{m}\left(B_{k}-B^{\prime}\right)^{2}}{m}} / B^{\prime}
$$

We therefore define the Indicator of Uniformity Dispersion, $(U)$ of the social benefit as:

$$
U=1-C V
$$

$U$ is a number less or equal to 1 , where 1 indicates the maximum uniform distribution. Its numerical result is relative, not absolute, and measures the uniformity of the orography of the social benefit resulting from the urban attractions.

This model also includes the possibility of introducing 'non-attractiveness' of the city (very busy streets, old abandoned factories, cemetery, etc.). This is simply done by introducing into the equations (4 and 5) an $A$ with a negative value ${ }^{8}$. The orographic result will be a concavity downwards and not upwards as was for the attractiveness 9 .

Each city, or a same city but in a different time period, will then have a specific isobenefit orography scenario. We can numerically quantify and compare these scenarios by several indicators: the Indicator of Uniformity Dispersion $(U)$ as an assessment of the effects of the spatial

\footnotetext{
${ }^{8}$ If we want to consider also the disamenities, $U$ will give some problems. Therefore, for $U$, we should separately consider amenities and disamenities.

${ }^{9}$ For the next simulation of the social benefit orography of Turin, the non-attractiveness being constant during the analysed years, will not be considered because, as constant, they will not change the result of the comparison.
} 
distribution of the attractions; the medium, minimum and maximum benefit (as medium, min, and max value of $\mathrm{M}$ ); the ratio between the difference of the maximum and the minimum benefit, and the minimum (Gap), that means a percentage difference between the benefit of the urban point with the best and the worst position on the planimetry of the city in relation to the location of the attractions and their levels.

Imagine to have a town without any attractions at all; just buildings where you live and work and streets to serve them (Fig. 15).

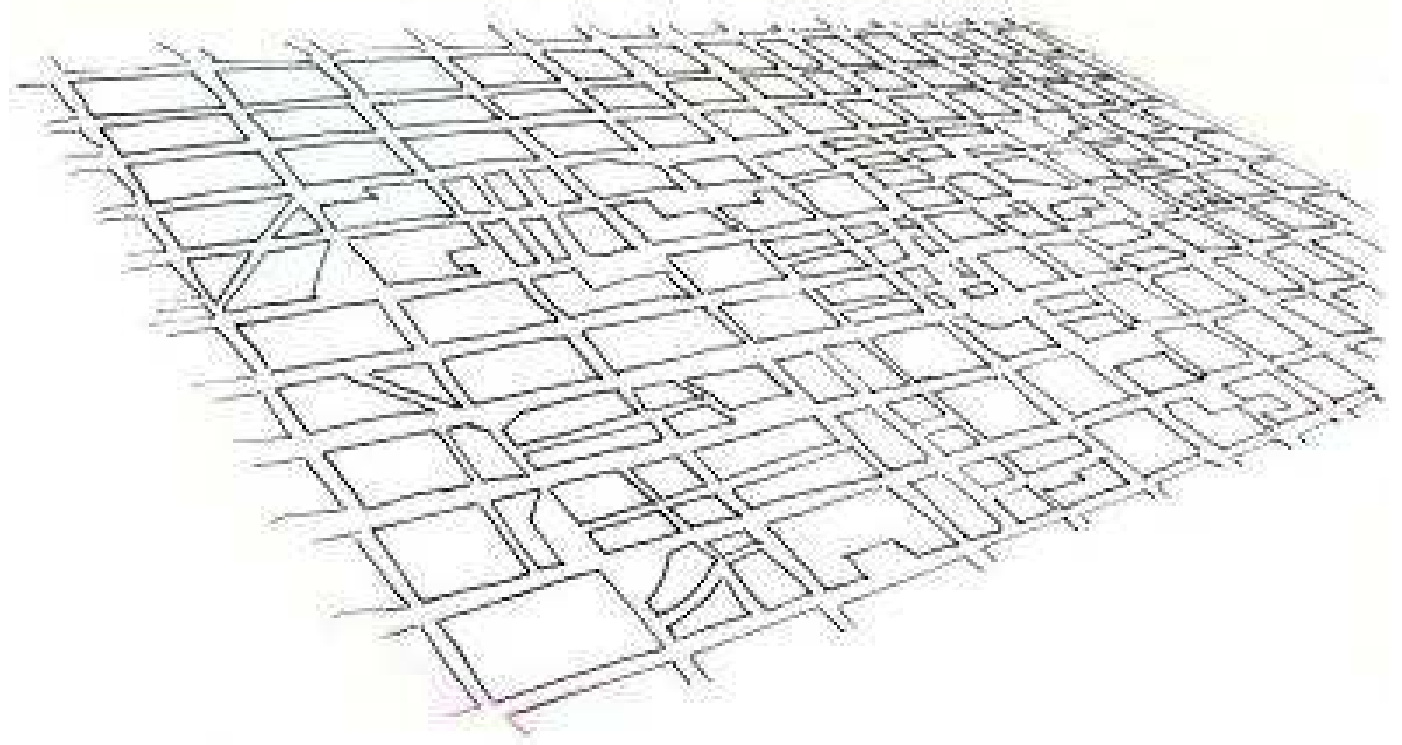

Fig. 15 Urban scenario I: city without any attractions

Now we imagine to have in that city a nice centre with a tower and historical building facing a pleasant square were the citizens are used to have social meetings, walks, relaxing on a bench, and so forth (Fig. 16), and we call it Attraction 1.

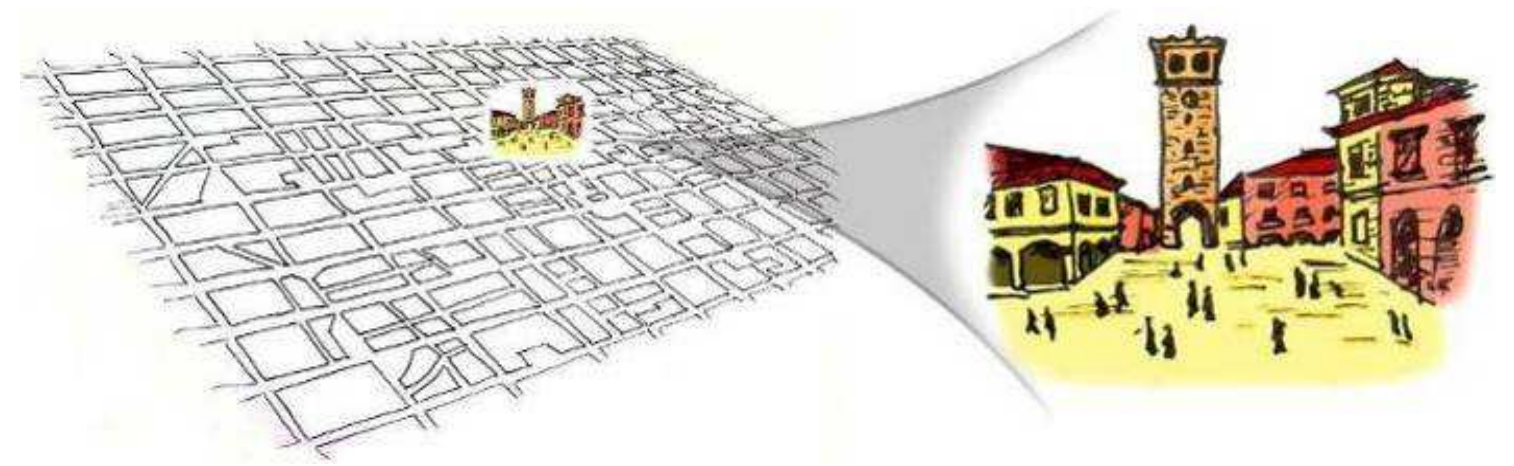

Fig. 16 Urban scenario II: one attraction. On the right zoom of Attraction 1

Subsequently we visualize to plan a new green area as shown in Fig. 17 (Attraction 2) 


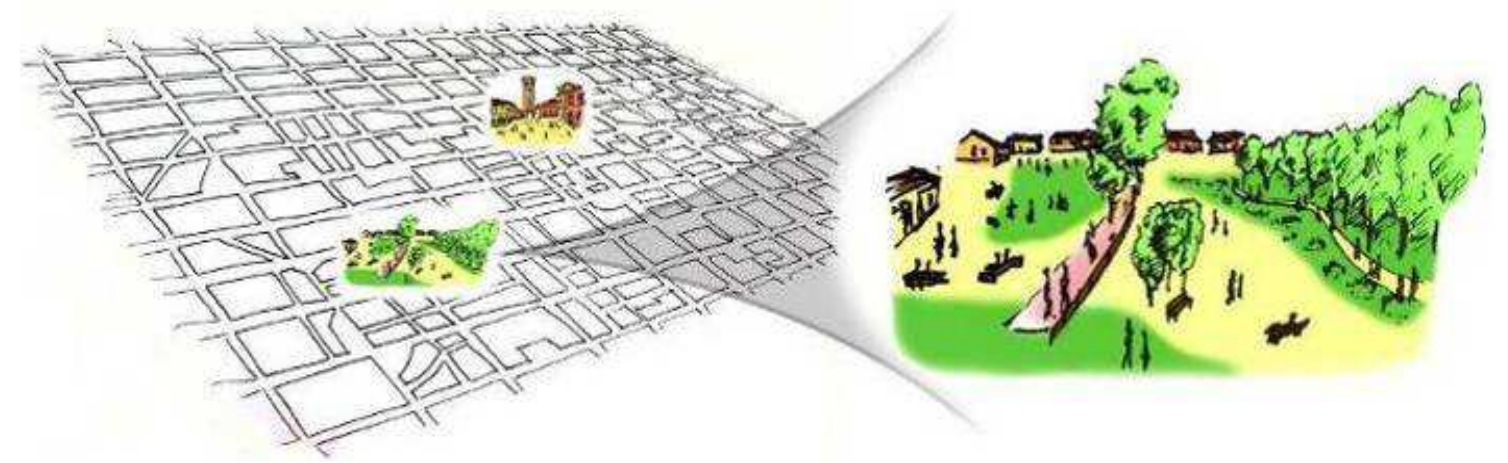

Fig. 17 Urban scenario III: two attractions. On the right zoom of Attraction 2

Afterwards we consider to plan an open space area, with a commercial centre, library, bar and restaurants, and water bodies (Fig. 18, Attraction 3).
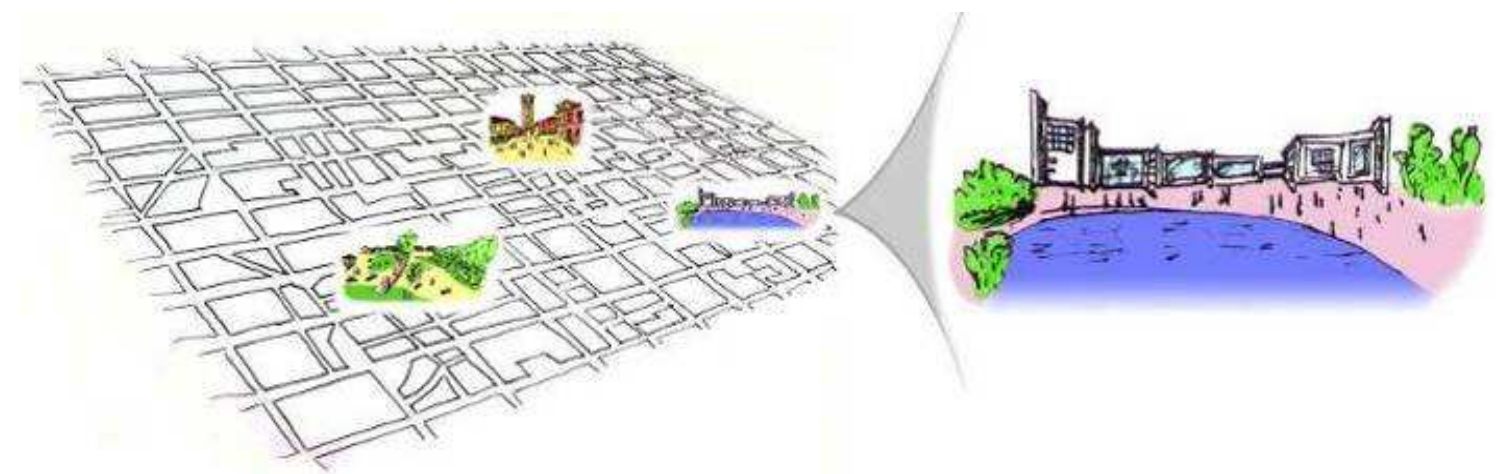

Fig. 18 Urban scenario IV: three attractions. On the right zoom of Attraction 3

Finally we imagine to transform a busy car parking place in an old city centre area, into a pedestrian area (Fig. 19, Attraction 4).

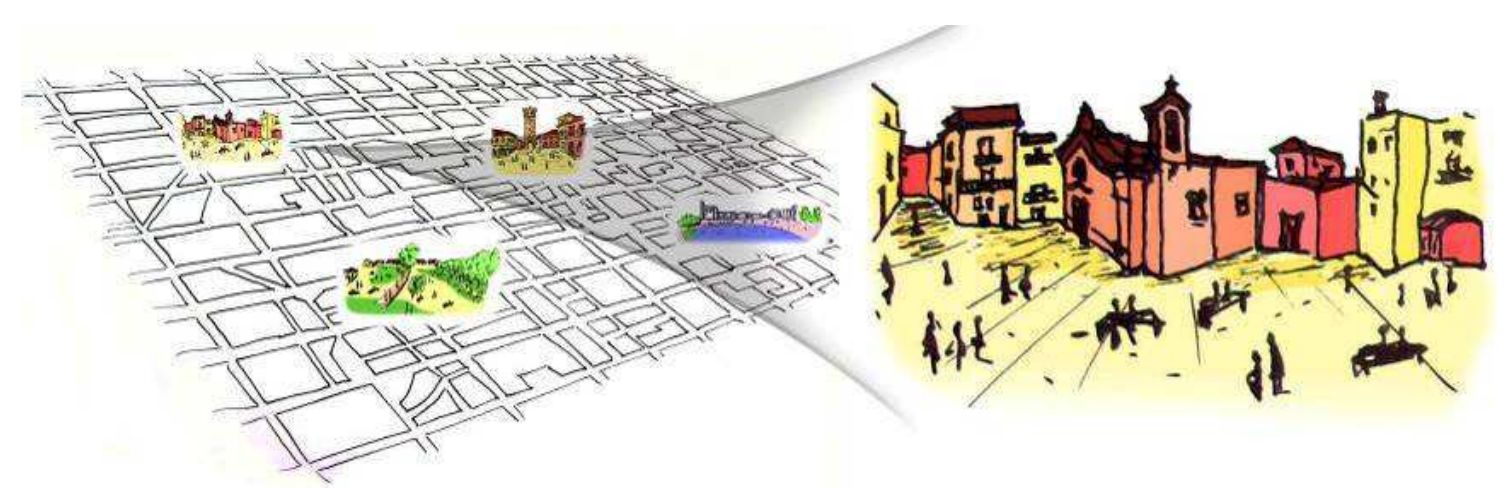

Fig. 19 Urban scenario V: four attractions. On the right zoom of Attraction 4

By a reciprocal comparison considering the average appreciation from the citizens and the number of people usually enjoying the attractions ${ }^{10}$, and using a scale between 1 (neutral urban point) and 3 (best attraction), we hypothesize to estimate $\mathrm{A}_{1}=3, \mathrm{~A}_{2}=1.5, \mathrm{~A}_{3}=2, \mathrm{~A}_{4}=1.7$.

\footnotetext{
${ }^{10}$ We should numerically judge how much an attraction can satisfy its pretension to be an 'Attraction' for the majority of citizens. It could be sensible to judge A by referring to the usual, average number of citizens (not tourists) using the attraction and by then comparing each amenity with the best place/s in the city and with the neutral ones. In a similar way, but in different contest and aim, urban economists have often been interested in using population levels as a measure of urban success. High levels of population "tell us that people are voting with their feet to move to a particular place" (Glaeser 2008). There is no doubt about the relativity, and then the validity, of our own preferences also if
} 
Next Fig. 20 shows the isobenefit orography and the isobenefit curves for each of the above scenarios.

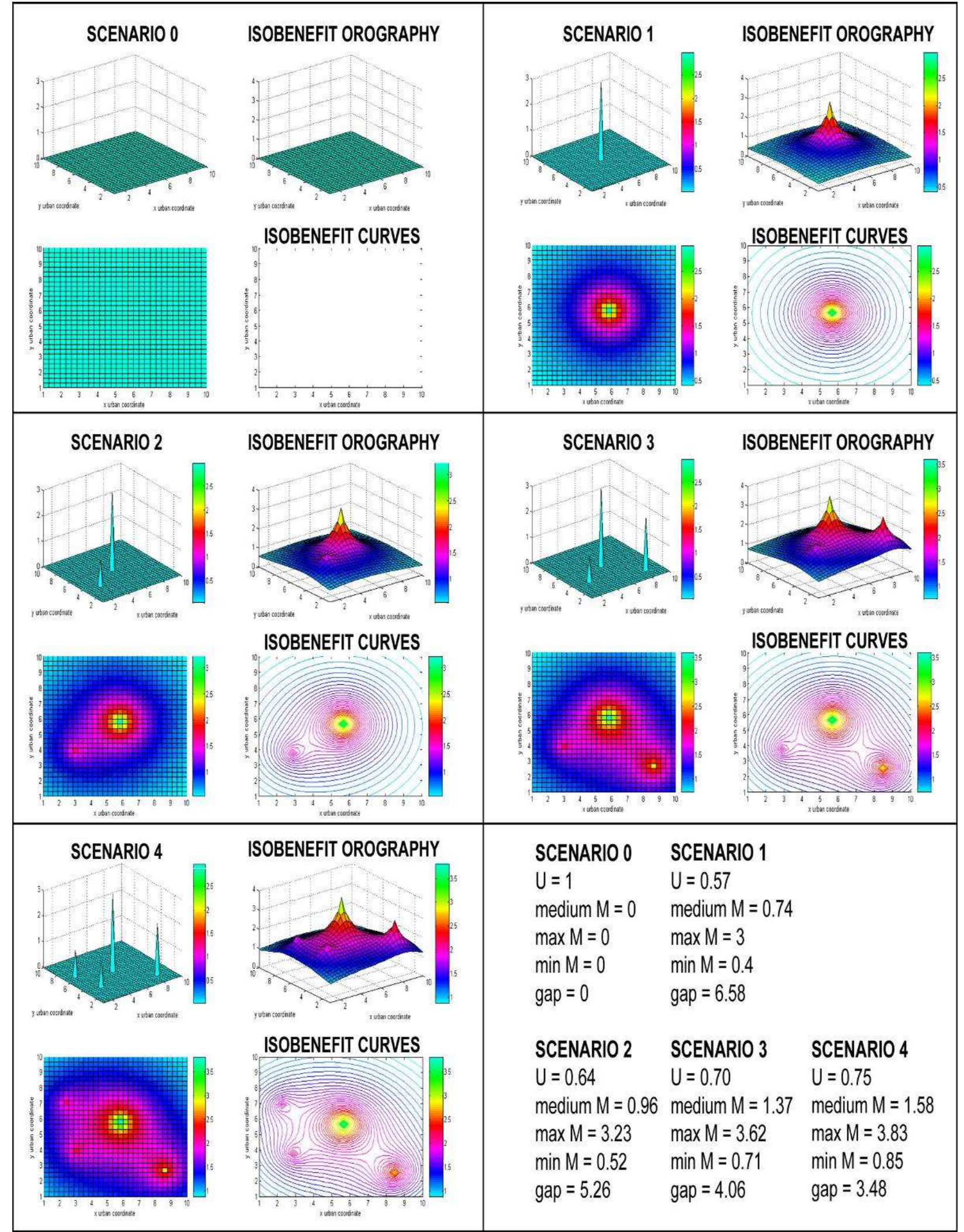

Fig. 20. Isobenefit orography of the scenarios

divergent from other people, or even from the average peoples preferences: that which for a person can be a wonderful attraction, i.e. a shopping mall, for another can be a boring, consumerist place. Idem for the judgment of amenities such as parks, historical areas, and so forth. For this is also proposed another kind of Isobenefit Analysis by the Personal Isobenefit Lines (D’Acci 2012d, e, f). 
Fig. 21 shows an example of real application of these measurements for Turin (D'Acci 2009 b). It indicates the amenities before (top), and after (bottom) the urban transformation occurred during the last decade (some because of the Olympic winter games and several policies of urban renovation of peripheries).
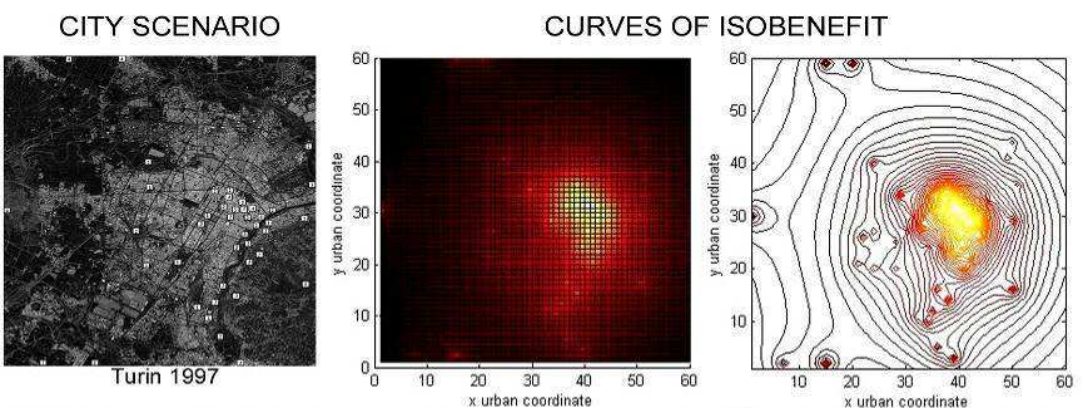

SOCIAL BENEFIT OROGRAPHY
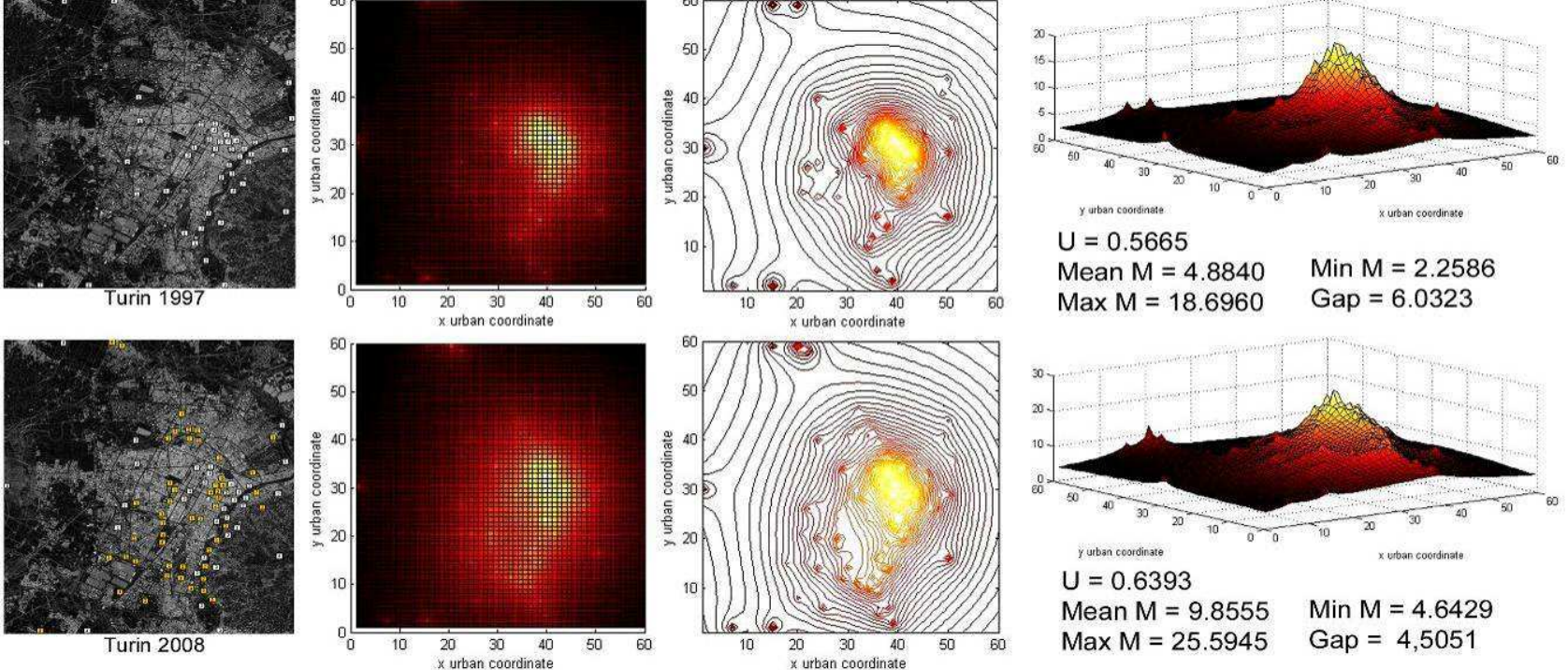

Fig. 21 Isobenefit Orography for Turin in 1997 and 2008

\subsection{Personal Isobenefit Lines}

The higher $E$ the more the equation 4 and 5 'weigh' the 'variety' advantage to enjoy numerous amenities, rather than the advantage of the proximity of one amenity. D'Acci (2012d) defined the first advantage as Variety Value, the second as Proximity Value.

In the next Fig. 22, people living in points 1 and 7 are in front of one amenity (A4 and A2); people in points 3 and 5, are slightly more distant from their closest amenity (A1 and A3), but the amenity has an higher attractiveness. It is like if the disadvantage to not live in front of the amenity is compensated from the higher benefit (higher A) that the citizen enjoys when reaching the amenity. At the same time, people living in 2, 4, 6 and 8 are more distant from their closest amenity, but enjoy the advantage to reach more than one amenity with the same effort.
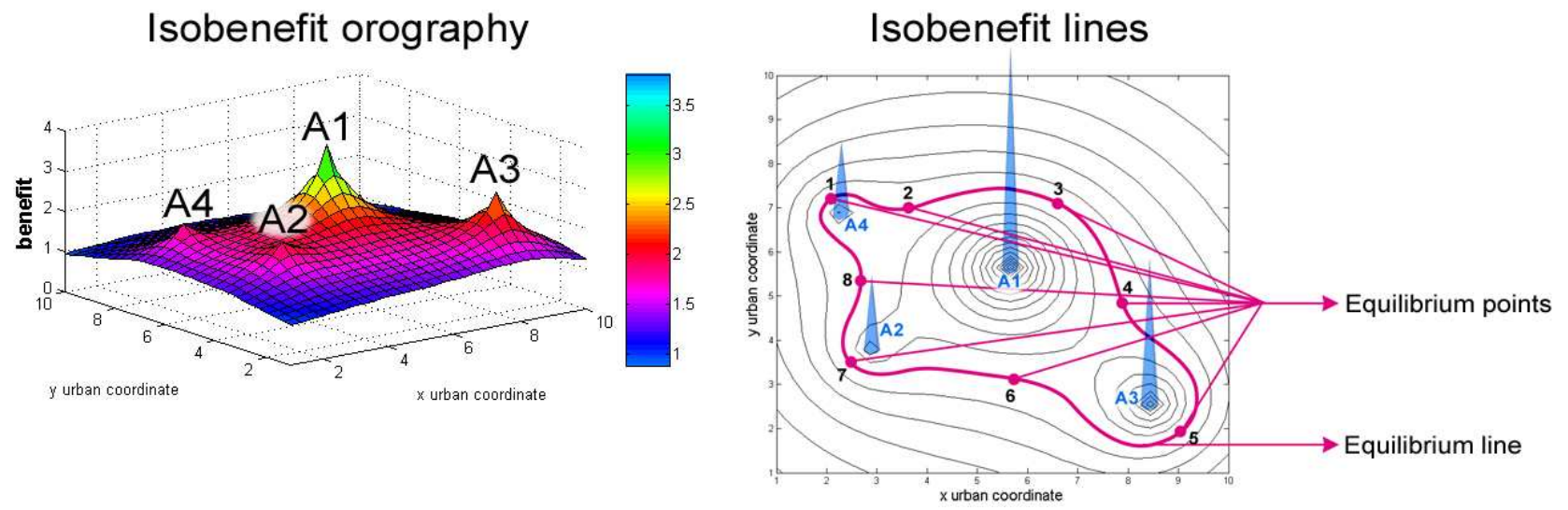

Fig. 22 Equilibrium points 
Personal Isobenefit Lines matches the preferences of each citizen. In fact Isobenefit Lines varies among people, and ages: one can prefer the variety to access more than one amenity, even paying the cost of not enjoying living very close to any amenity (although with a low attractiveness).

Therefore, when we build Personal Isobenefit Lines, $E$ will also estimate the personal propensity to move, and the personal preference for the Variety Value (directly proportional to $E$ ) rather than for the Proximity Value (inversely proportional to $E$ ).

Isobenefit Lines can also be personalized when each person feels different levels of attractiveness for a same amenity ${ }^{11}$.

\section{A monetary indicator as a social indicator}

Starting with the assumption that part of the real estate value is a monetary mirror of the ULQ that a citizen is expected to receive by buying and living in a certain urban point, with due caution and technical devices, the property value can be used as a social indicator of the average quality of the city areas. Just considering the Pleasantness given from city Centralities $(P C)$, we can see a similarity between the above curves of isobenefit (Fig. 21) and the property value (Fig. 8): Fig. 23 shows this comparison for Turin ${ }^{12}$.

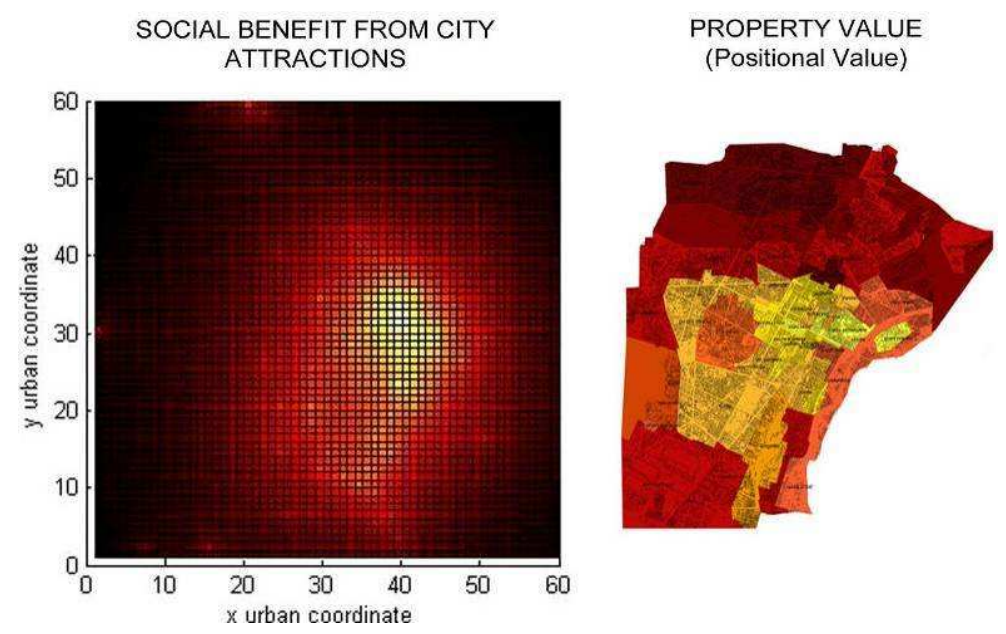

Fig. 23 Turin (2008). Property value (right) as indicator of social benefit from PC (left)

As we can see from Fig. 21, the urban transformation created a more uniform distribution of the amenities. Numerically we can also notice this by the coefficient of variation of the urban matrix M, $\mathrm{CV}$, that decreased by $17 \%$ during the period of time considered (1997-2008) of urban transformations. The coefficient of variation $(\mathrm{CV})$ of the real estate value in Turin decreased by almost the same value (15\%) during the same period of time considered, and in respect to the average national level (D'Acci 2009b). If we also compare the increase of the benefit of the urban point $\left(B_{k}\right)$ in the entire city (average value), in the central, semicentral, and peripherical area with the increase, in the same areas, of the real estate value ${ }^{13}$ during the same time period we can notice

\footnotetext{
${ }^{11}$ We can visualize the Breaking point of equal attraction among amenities (which can be personal) as the point at which a marble placed in the Isobenefit surface settles (D'Acci 2012d).

${ }^{12}$ The Positional Value colour legend has been inverted in order to allow a better visual comparison.

${ }^{13}$ For the coefficient of variation of the Property Value it was possible to use the values of a high number of areas for each city thanks to the Gabetti Agency data set. This allows us an excellent measurment of the value spatial distribution. For this coefficient we considered just the most important cities in Italy (Roma, Milano, Napoli, Torino, Genova, Bologna, Firenze, Bari), thinking it is more correct for a comparison with the urban dimension of Turin. The years used are 1997 and 2005 because there are some differences among the urban areas used in the data of 1997 and in 2008, and we would utilize the same values to get a more correct result. The increase for each city is: Roma $=+9 \%$, Milano $=-$
} 
some analogy (fig. 24) (D'Acci 2009b). The average value of the city for all the 103 Italian cities was calculated; then their peripherical, central and semicentral values. Afterwards the Turin increase has been calculated by the difference between the Turin values and the national average ones. In this way we can isolate the specific behaviour of Turin, without considering that part of increase/decrease due from the national trend (Tab. 2).

Tab. 2

INCREASE OF THE PROPERTY VALUE 1997/2008

$\begin{array}{lllll}\text { Type of value } & \text { Turin } & \text { National average } & \begin{array}{l}\text { National average } \\ \text { without outliers }\end{array} & \begin{array}{l}\text { Relative Turin } \\ \text { increase }\end{array} \\ \text { average (all the city) } & 77 \% & 87 \% & 70 \% & 7 \% \\ \text { average peripherical } & 86 \% & 81 \% & 65 \% & 21 \% \\ \text { average semicentral } & 75 \% & 86 \% & 65 \% & 10 \% \\ \text { average central } & 72 \% & 94 \% & 69 \% & 3 \% \\ \text { coefficient of variation } & -30 \% & -5 \% & -15 \% & -15 \% \\ \text { (CV) } & & & \end{array}$

INCREASE 1997/2008-5

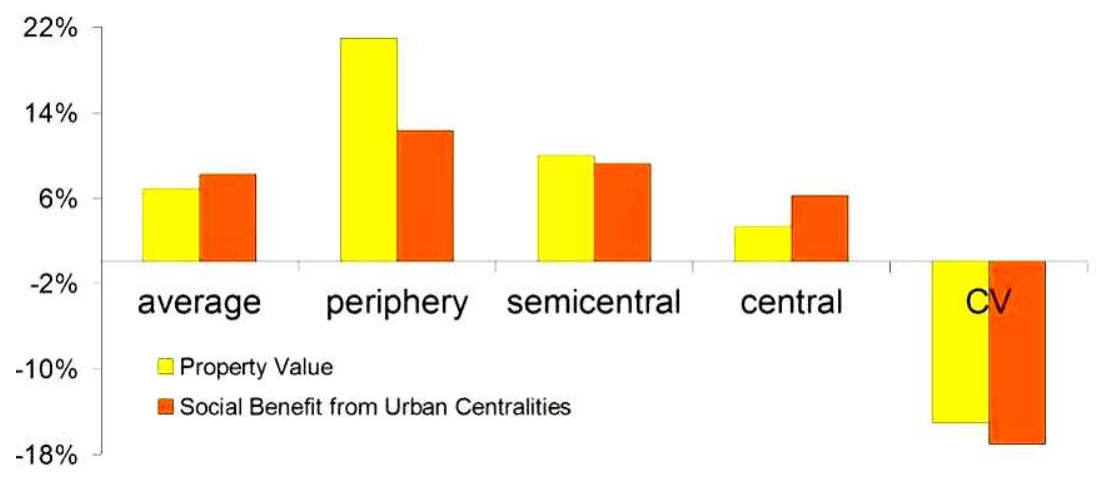

Fig. 24 Percentage increase of Property value and Social Benefit from City Centralities $(P C)$ in Turin 1997-2008

The increases show a quiet similarity, apart from the periphery and the central area of the city. This is probably due to several reasons such as: the fact the Turin, during the same range of years considerate, has developed a underground transport lines plan and various important projects of periphery renovation.

One of the effects that, usually, a new underground line (or in general any good public transport policy improving the connection of peripherical areas to the city, and especially to the city centre), is expected to have is a property value increase of the peripherical area covered by the new public transport lines, and a contemporary decrease of the central area property value could also happen.

Regarding the several plans of periphery renovation ${ }^{14}$, we remind that Fig. 21 does not consider all the Pleasantness given from the Background 'daily urban quality' (PB) (Fuzzy Urban Quality) such as a general soft and spread requalification of the buildings quality, local streets quality, social context etc.

$16 \%$, Napoli $=-10 \%$, Torino $=-30 \%$, Genova $=-20 \%$, Bologna $=+68 \%$, Firenze $=-19 \%$, Bari $=-21 \%$. The outlier considered is Bologna. I want to evidence that the data set of Roma does not give too much assurance because I had had to use just a few areas to have the same areas in 1997 and 2005, because some differences among the data set of Gabetti used during the considered years.

${ }^{14}$ www.comune.torino.it/rigenerazioneurbana/en/ 
Another relevant source of error in the comparison between the Positional Value and the Urban Social Benefit Orography (Fig. 23), is the fact that the real estate sample to deduce the Positional Value does not cover every $k$ point of the city (the matrix M). On the contrary, the Urban Social Benefit Orography is based on the benefit $\left(B_{k}\right)$ calculated for every $k$ point of M. Therefore the average Positional Value of an area is the mean of the units of the sample available for that area, and they cannot be properly representative of all the area, and of all the attractions of the area, because they could be non uniformly distributed throughout the area and, especially, non uniformly spatially distributed in relation with the attractions.

\section{Conclusion}

Everybody knows what makes city life better (parks, gardens, pedestrian areas, buildings and street beauty, cultural stimulation, good public transportation systems...), and worse (crime, congestion, pollution, anonymity, alienation...). More and more often it is appearing necessary to measure this amount of pleasentess/unpleasentess, and to assess its determinants, in order to give a concrete value to use inside policies and investment decisions.

This paper showed some examples to do it, passing by monetary, subjective or quantitative approaches. Some monetary methods applied on Turin, has shown how the quality of the area can change the property value (Positional Value) up to $143 \%$, and how people expressed a willingnessto-pay of around $540 € /$ year for an improvement of the quality of the area where they live. As a quantitative approach the concepts of Urban Centralities and Fuzzy Urban Quality and a way to measure the quantity, the quality and the uniform distribution of attractions in cities were proposed. As result, I presented the concepts of Social Isobenefit Lines and Urban Orography of the Social Benefit. Finally a comparison between the Orography of the Social Benefit and the Positional Value calculated for Turin before and after some deep urban transformations, occurred approximately during the years 1997 and 2008, has shown a reasonable similarity, especially concerning the more uniform distribution of amenities (and, therefore, of 'quality of life') throughout the city.

\section{References}

Allen, W. B., Chang, K., Marchetti, D., \& Pokalski, J. (1986). Value capture in transit: The case of the Lindenwold high speed line. The Wharton Transportation Program, The Wharton School, University of Pennsylvania.

American Planning Association (2002). City Parks Forum Briefing Papers.

Anderson, S. T. \& West, S. E. (2006) Open space, residential property values and spatial context. Regional Science and Urban Economics 36: 773-789.

Bajic, V. (1983). The effects of a new subway line on housing prices in metropolitan Toronto. Urban Studies, 2, 147158.

Bateman, I., Day, B., Lake, I., and Lovett, A. (2001). The Effect of Road Traffic on Residential Property Values: A Literature Review and Hedonic Pricing Study. Report to the Scottish Executive Development Department. School of Environmental Sciences, University of East Anglia, Norwich.

Benjamin, J. D. \& Sirmansm G.S. (1996). Mass Transportation, Apartment Rent and Property Values. The Journal of Real Estate Research 12, 1-8.

Benson, E.D., Hansen, J.L., Schwartz Jr., A.L., Smersh, G.T., (1998). Pricing residential amenities: the value of a view. J. Real Estate Finance Econ. 16, 55-73.

Bianchini, F. (1990). The crisis of urban social life in Britain: origins of the problems and possible responses. Planning Practice and Research, 5 (3), p. 4.

Blanco, J. C. \& Flindell, I., (2011). Property prices in urban areas affected by road traffic noise. Applied Acoustics 72 , 133-141.

Bolitzer, B., Netusil, N.R., (2000). The impact of open spaces on property values in Portland, Oregon. J. Environ. Manage. 59 (3), 185-193.

Bolund, P., Hunhammar, S., 1999. Ecosystem services in urban areas. Ecol. Econ. 29, 293-301.

Bourassa, S.C., Hoesli, M., Sun, J., (2004). What's in a view? Environ. Plann. A 36, 1427-1450.

Bowes, D. R., \& Ihlanfeldt, K. R. (2001). Identifying the Impacts of Rail Transit Stations on Residential Property Values. Journal of Urban Economics, 50, 1-25. 
Brander, L.M., Koetse, M.J. (2011). The Value of urban open space: meta-analyses of contingent valuation and hedonic pricing results. Journal of Environmental Management ,92(10), 2763-2773.

Breffle, W., Morey, E., \& Lodder, T. (1998). Use of contingent valuation to estimate a neighbourhood's willingness to pay to preserve undeveloped urban land. Urban Studies, 35, 715-727.

Cervero, K. R. \& Kang, C. D., (2011). Bus rapid transit impacts on land uses and land values in Seoul, Transport Policy, vol. 18, 1, 102-116

Cervero, R. (1996). Transit-based housing in the San Francisco Bay area: Market profiles and rent premiums. Transportation Quarterly, 50(3), 33-47.

Chen, Z., \& Davey, G. (2008). Subjective quality of life in Zhuhai City, South China: A public survey using the international wellbeing index. Social Indicator Research, 91, 243-258.

Colliers Erdman Lewis, (1995). Colliers Erdman Lewis How to Get Pedestrian Rental Growth. Colliers Erdman Lewis Research and Consultancy, London.

Costanza, R., d'Arge, R., de Groot, R., Farber, S., Grasso, M., Hannon, B., Laskin, R., Sutton, P., van den Belt, M., (1997). The value of the world's ecosystem services and natural capital. Nature 387 (15), 253-260.

Crompton, J. L. (2001). The impact of parks on property values: A review of the empirical evidence. Joumal of Leisure Research, 33, 1-31

D’Acci, L. (2007), Formazione e simulazione dei valori immobiliari, Ph.D Thesis, Politecnico di Torino.

D'Acci, L. (2008). Grown, urban transformation, real estate value: Econometric cellular automata for the simulation of positional value. Lecture Notes in Computer Science, LNCS 5072.

D’Acci, L. (2009a). A mathematical aid for efficient distribution of social benefit in urban planning. In Rabino., G. \& Scarlatti, F. (Ed.). Advances in Models and Methods for Planning. Bologna: Pitagora.

D'Acci, L. (2009b). Spatial distribution of social benefit given by urban attractions. Lecture Notes in Computer Science LNCS 5592, pp. 237-252.

D'Acci, L. (2010). Measuring Well-Being and Progress. Social Indicators Research, Vol 104, Number 1, 47-65.

D'Acci, L. (2010). A spatial multicriteria decision analysis to plan new urban poles in metropolies. In Las Casas, G., Pontrandolfi, P., \& Murgante B. (Ed.). Informatica e Pianificazione Urbana e Territoriale. Melfi: Libria, Vol.1(pp. 321-330).

D'Acci, L. \& Lombardi, P. (2010). MuSIC - A new Multi-scalar index for evaluating Sustainability in Cities. In Lehmann, S., Al Waer, H. \& Al-Qawasmi, J. (Ed.). Sustainable Architecture \& urban development. CSAAR - Center for the Study ofArchitecture in Arab Region (JOR).

D'Acci, L. (2012a). The Positional Value: influence of city area on the real estate value. (Under review).

D'Acci, L. (2012b). Urban quality of Life Estimates, Encyclopedia of Quality of Life Research, Springer (in press).

D'Acci, L. (2012c). Hedonic inertia and underground happiness, Social Indicators Research.

D'Acci, L. (2012d). Isobenefit Lines, Breaking Point of equal attraction, Uniformity Benefit, Variety Value and Proximity Value, Preference Gap Gain, General Finance (q-fin.GN); Physics and Society (physics.soc-ph), Cornell University Library. http://arxiv.org/abs/1210.7510

D’Acci,L. (2012e). Modeling Spatial Equilibrium in Cities: the Isobenefit Lines, General Finance (q-fin.GN); Physics and Society (physics.soc-ph), Cornell University Library. http://arxiv.org/abs/1210.4461

D’Acci, L. (2012f). Urban Isobenefit Lines, Encyclopedia of Quality of Life Research, Springer (in press).

Das, D. (2008). Urban quality of life: A case study of Guwahati. Social Indicators Research, 88, $297-310$.

Damigos, D. and Anyfantis, F. (2011). The value of view through the eyes of real estate experts: A Fuzzy Delphi Approach. Landscape and Urban Planning 101(2), pp. 171-178.

Debrezion, G., Pels, E., Rietveld, P., (2007). The impact of railway stations on residential and commercial property value: a meta-analysis. The Journal of Real Estate Finance and Economics 35, 161-180.

Dewees, D. N., (1976). Congestion costs in urban motoring: Some Toronto estimates. Centre for Urban and Community Studies, University of Toronto (Toronto).

Diamantini, C., Zanon, B., 2000. Planning the urban sustainable development: the case of the plan for the province of Trento, Italy. Environ. Impact Asses. 20, 299-310.

Ding, C., Simons, R., and Baku, E. (2000). The effect of residential investment on nearby property values: Evidence from Cleveland, OH. The Journal of Real Estate Research, 19(1), 23-48.

Doss, C.R., Taff, S.J., (1996). The influence of wetland type and wetland proximity on residential property values. J. Agric. Resour. Econ. 21, 120-129.

Dueker, K. J., \& Bianco, M. J. (1999). Light rail transit impacts in Portland: The first ten years. Presented at Transportation Research Board, 78th Annual Meeting.

Dunn, M.B., (1986). Property values and potentially hazardous production facilities: a case study of the Kanawha Valley, West Virginia. Ph.D. Dissertation, Florida State University, Tallahassee, Florida.

Dunning, H., Williams, A., Abonyi, S., \& Crooks, V. (2008). A mixed method approach to quality of life research: A case study approach. Social Indicator Research, 85, 145-158.

Easterlin, R.A., Angelescu, L., \& Zweig, J.S. (2011). The Impact of Modern Economic Growth on UrbanRural Differences in Subjective Well-Being. World Development. Vol. 39, No. 12. 2187-2198. 
Epley, D. R., \& Menon, M. (2008). A method of assembling cross-sectional indicators into a community quality of life. Social Indicators Research, 88, 281-296.

Espey, M. \& Lopez, H. (2000). The impact of airport noise and proximity on residential property values. Growth and Change 31 408-419.

European Federation for Transport and Environment (EFTE), 2002. Transport and the Economy: Myths and Facts 2002. Transport, Infrastructure and the Economy: A TandE Fact-Sheet 2002.

Evans, R. (1997). Regenerating town centres. Manchester: Manchester University Press.

Fejarang, R. A. (1994). Impact on property values: A study of the Los Angeles metro rail. Washington, DC: Transportation Research Board, preprint, Transportation Research Board, 73rd Annual Meeting, January 913.

Fennema, A.T., Veeneklaas, F.R., Vreke, J., (1996). Meerwaarde woningen door nabijheid van groen (Surplus value of dwellings in the vicinity of green areas). Stedebouw en Ruimtelijke Ordening 3, 33-35.

Frederick, R., Goo, R., (1996). Economic Benefits of Urban Runoff Controls. Urban Sources Section, Assessment and Watershed Protection Division. U.S. Environmental Protection Agency, Washington, DC.

Gehl, J., Gemzøe, L., (1999). Public Spaces-Public Life. Copenhagen. Danish Architectural Press and the Royal Danish Academy of Fine Arts. School of Architecture Publishers.

Glaeser E. (2008). Cities, Agglomeration, and Spatial Equilibrium, Oxford University Press.

Grasso, M., \& Canova, L. (2008). An assessment of the quality of life in the European Union based on the social indicators approach. Social Indicator Research, 87, 1-25.

Graves, P., Murdoch, J.C., Thayer, M.A., Waldman, D., (1988). The robustness of hedonic price estimation: urban air quality. Land Econ. 64, 220-233.

Hass-Klau, C. \& Crampton, G., (2002). Future of Urban Transport, Learning from Success and Weakness: Light Rail. ETP, Brighton.

Hass-Klau, C. (1993). Impact of pedestrianization and traffic calming on retailing. A review of the evidence from Germany and the UK. Transport Policy, Volume 1, Issue 1, Pages 21-31.

Hill, R. (2011). Hedonic Price Indexes for Housing. OECD Statistics Working Papers, 2011/01, OECD Publishing. http://dx.doi.org/10.1787/5kghzxpt6g6f-en

Hui, E.C.M., Chau, C.K., Pun, L., Law, M.Y., (2007). Measuring the neighboring and environmental effects on residential property value: using spatialweighting matrix. Build. Environ. 42, 2333-2343.

Husted, R. J. \& Anker, N. O., (2004). Assessment of Traffic Noise Impacts. International Journal of Environmental Studies. Sections A \& B, Vol. 61, No. 1, 2004, p. 19-30.

Kask, S.B., Maani, A., (1992). Uncertainty, information and hedonic pricing. Land Econ. 68, 170-184.

Ibeas, A., Cordera, R., dell'Olio, L., Coppola, P., Dominguez, A., (2012). Modelling transport and real-estate values interactions in urban systems. Journal of Transport Geography Volume 24, 370-382.

Lake, I., Lovett, A.A., Bateman, I.J. and Langford, I.H. (1998). Modelling environmental influences on property prices in an urban environment. Computers, Environment and Urban Systems, 22(2), 121-136.

Li, F., Liu, X., Hu, D., Wang, R., Yang, W., Li, D., Zhao, D. (2009). Measurement indicators and an evaluation approach for assessing urban sustainable development: A case study for China's Jining City. Landscape and Urban Planning 90 (2009) 134-142.

Lopes, M.N., and Camanho, A.S. (2012). Public Green Space Use and Consequences on Urban Vitality: An Assessment of European Cities. Social Indicators Research.

Luttik, J., (2000). The value of trees, water and open space as reflected by house prices in the Netherlands. Landscape and Urban Planning 48, 161-167.

Lutzenhiser, M. and Netusil, N. R. (2001), The Effect of Open Spaces on a Home's Sales Price. Contemporary Economic Policy, 19: 291-298.

Jenny, A., Ericson, A., (2006). A participatory approach to conservation in the Calakmul Biosphere Reserve, Campeche, Mexico. Landscape Urban Plan. 74, 242-266.

Jim, C.Y. and Chen, W.Y. (2009). Value of Scenic Views: Hedonic Assessment of Private Housing in Hong Kong. Landscape Urban Planning.

Jim, C.Y. \& Chen, W.Y. (2007). Consumption preferences and environmental externalities: A hedonic analysis of the housing market in Guangzhou. Geoforum. 38. 414-431.

Jim, C.Y. and Chen, W.Y. (2006). Impacts of Urban Environmental Elements on Residential Housing Prices in Guangzhou (China), Landscape and Urban Planning, Vol. 78, pp. 422- 434.

Johansson, S. (2002). Conceptualizing and measuring quality of life for national policy. Social Indicators Research, 58, 13-32.

Joint Center for Urban Mobility Research (1987). Assessment of Changes in Property Values in Transit Areas.

Marans, R.W., \& Stimson, R. (2011). Investigating quality of urban life: Theory, methods, and empirical research. Social Indicators Research Series, 45, 1-29.

McLeod, P.B., (1984). Thedemandfor local amenity: an hedonic price analysis. Environ. Plann. A 16, $389-400$.

McMillen, D.P. (2004). Airport expansions and property values: the case of Chicago O'Hare Airport. Journal of Urban Economics 55, 627-640. 
Mendelsohn, R., Hellerstein, D., Huguenin, M., Unsworth, R., Brazee, R., (1992). Measuring Hazardous Waste Damages with Panel Models. Journal of Environmental Economics and Management 22, no. 3, 259-71.

Michaels, R. Gregory \% V. Kerry Smith (1990). Market Segmentation and Valuing Amenities with Hedonic Models: The Case of Hazardous Waste Sites. Journal of Urban Economics 28, no. 2, 223-42.

MIT Technology Review, Isobenefit Lines Rewrite Rules for Understanding City Life. http://www.technologyreview.com/view/429679/isobenefit-lines-rewrite-rules-for-understanding-city-life/

Morancho, A. (2003). A hedonic valuation of urban green areas. Landscape Urban Plan. 66, 35-41.

Morano, P. (2006). Analisi di regressione per le valutazioni di ordine estimativo. Torino: Celid.

Nelson, A. C. (1992). Effects of Elevated Heavy-Rail Transit Stations on House Prices with Respect to Neighborhood Incomes. Transportation Research Record 1359, 127-132.

Neupane, A. \& Gustavson, K. (2008). Urban property values and contaminated sites: A hedonic analysis of Sydney, Nova Scotia. Journal of Environmental Management 88, 1212-1220.

Newby, L., (1992). Paved with Gold-A Study of the Economic Impact of Pedestrianisation and its Relevance to Leicester. Research Report No. 7. Leicester Environment City Trust. December.

Okulicz-Kozaryn, A. (2011). City Life: Rankings (Livability) Versus Perceptions (Satisfaction). Social Indicators Research.

Pacione, M. (2003). Introduction on urban environmental quality and human wellbeing. Landscape and Urban Planning 65 (2003) $1-3$.

Pearson, C.A., (2000). Making Good Design Pay Off. Fourth Annual Business Week/Architectural Records Awards. Architectural Record 188 (10), 84-99.

Poudyal, N. C., Hodges D. G., \& Merrett, C. D. (2009). A hedonic analysis of the demand and benefits of urban recreation parks. Land Use Policy, 26(4), 975-983.

Rezvani, M.R., Mansourian, H. and Sattari, M.H. (2012). Evaluating Quality of Life in Urban Areas. Social Indicators Research.

Rodriguez, D.A. \& C.H. Mojica (2009). Capitalization of BRT network expansions effects into prices of non-expansion areas, Transportation Research Part A, 43,5, 561-575.

Romano, O. \& Ercolano, S. (2012). Who Makes the Most? Measuring the "Urban Environmental Virtuosity. Social Indicators Research.

Rossouw, S., \& Naude, W. (2008). The non-economic quality of life on a sub-national level in South Africa. Social Indicators Research, 86, 433-452.

Saretzki, A., Wo“hler, K. (1995). Verkehrsentwicklungsplan, Umsatzentwicklung und Kundenverhalten, Industrie-und Handelskammer Lüneburg. Transport Development Plan: Turnover and Customer Behaviour, Lüneburg. (not officially published).

Shearer, A.W., Mouat, D.A., Bassett, S.D., Binford, M.W., Johnson, C.W., Saarinen, J.A., (2006). Examining development-related uncertainties for environmental management strategic planning scenarios in Southern California. Landscape Urban Plan. 77, 359-381.

Schaerer, C., Baranzini, A., Ramirez, J. W., Thalmann, P. (2007). Using the Hedonic Approach to Value Natural Land Uses in an Urban Area: An Application to Geneva and Zurich. Économie publique/Public economics 20 $(2007 / 1)$

Schell, L.M., Ulijaszek, S.J., (1999). Urbanism, Health and Human Biology in Industrialized Countries. Cambridge University Press, London, pp. 59-60.

Simonotti, M. (1997). La stima immobiliare. Torino: Utet.

Simons, R.A., Quercia, R.G., Levin, I. M. (1998). The Value Impact of New Residential Construction and Neighborhood Disinvestment on Residential Sales Price. Journal of Real Estate Research, Vol 15, Issue 2, 147- 61 .

Smith, B.H., (1994). Coastal setback and the impact of water amenities. Geogr. Anal. 26, 364-369.

Smolen, G.E., Moore, G., Conway, L.V., (1991). Economic effects of hazardous waste landfills on surrounding real estate values in Toledo, Ohio. Research Report no. 44, Center for Real Estate Education and Research, Ohio State University.

Tajima, K., (2003). New estimates of the demand for urban green space: implications for valuing the environmental benefits of Boston's big dig project. J. Urban Affairs 25, 641-655.

Tse, R.Y.C., (2002). Estimating neighborhood effects in house prices: towards a new hedonic model approach. Urban Stud. 39, 1165-1180.

Tyrvainen, L., Miettinen, A., (2000). Property prices and urban forest amenities. J. Environ. Econ. Manage. 39, 205223.

Troy, A. \& Grove, J. M., (2008). Property values, parks, and crime: A hedonic analysis in Baltimore, MD. Landscape and Urban Planning 87 (2008) 233-245

Ulengin, B., Ulengin, F. \& G uvenc, U. (2001). A multidimensional approach to urban quality of life: The case of Istanbul. European Journal of Operational Research. 130. 361-374.

van Poll, R. (1997). The perceived quality of the urban residential environment. A Multi-Attribute Evaluation. Roermond. Printing Westrom. 
Voith, R. (1991). Transportation, sorting and house values. Journal of the American Real Estate Urban Economics Association, 19, 117-137.

Wachter, S. and Gillen, K. (2006). Public Investment Strategies: How they Matter for Neighborhoods in Philadelphia: Identification and Analysis. Pennsylvania Horticultural Society: Philadelphia.

Weinberger, R. (2001). Light rail proximity: Benefit or detriment, the case of Santa Clara County, California. Washington, DC: Transportation Research Board (presented at Transportation Research Board 80th Annual Meeting, January 7-11).

Weinstein, B. L. \& Clower, T. L. (1999). The Initial economic Impacts of the Dart Lrt System. Transportation Research Board.

Wen, Z. \& Chen, J. (2008). A cost-benefit analysis for the economic growth in China. Ecological Economics. 65. 356366.

Wu, J., Adams, R., Plantinga, A. (2004). Amenities in an Urban Equilibrium Model: Residential Development in Portland, Oregon. Land Economics 80: 19-32. 